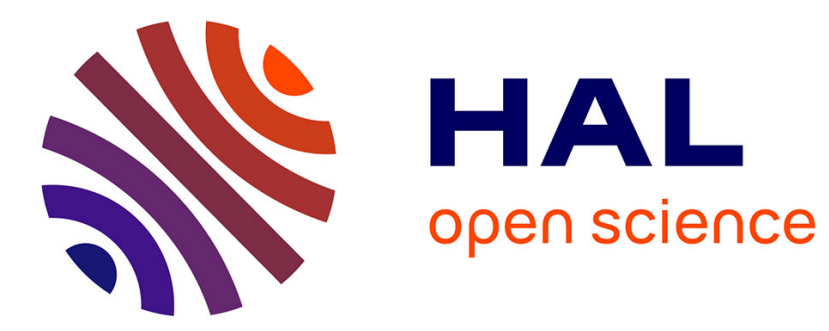

\title{
Understanding time perception through non-invasive brain stimulation techniques: A review of studies
}

\author{
G. Mioni, S. Grondin, Lara Bardi, F. Stablum
}

\section{To cite this version:}

G. Mioni, S. Grondin, Lara Bardi, F. Stablum. Understanding time perception through non-invasive brain stimulation techniques: A review of studies. Behavioural Brain Research, 2020, 377, pp.112232. 10.1016/j.bbr.2019.112232 . hal-03038412

\section{HAL Id: hal-03038412 \\ https://hal.science/hal-03038412}

Submitted on 7 Dec 2020

HAL is a multi-disciplinary open access archive for the deposit and dissemination of scientific research documents, whether they are published or not. The documents may come from teaching and research institutions in France or abroad, or from public or private research centers.
L'archive ouverte pluridisciplinaire HAL, est destinée au dépôt et à la diffusion de documents scientifiques de niveau recherche, publiés ou non, émanant des établissements d'enseignement et de recherche français ou étrangers, des laboratoires publics ou privés. 


\section{Journal Pre-proof}

Understanding time perception through non-invasive brain stimulation techniques: A review of studies

G. Mioni, S. Grondin, L. Bardi, F. Stablum

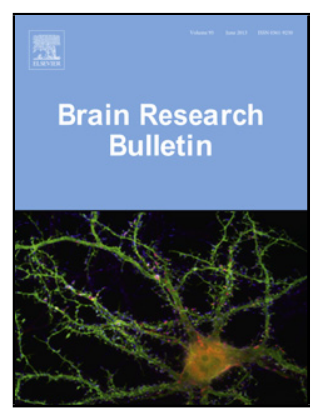

PII:

S0166-4328(19)30673-4

DOI: https://doi.org/10.1016/j.bbr.2019.112232

Reference:

BBR 112232

To appear in:

Behavioural Brain Research

Received Date:

28 May 2019

Revised Date:

6 September 2019

Accepted Date:

11 September 2019

Please cite this article as: Mioni G, Grondin S, Bardi L, Stablum F, Understanding time perception through non-invasive brain stimulation techniques: A review of studies, Behavioural Brain Research (2019), doi: https://doi.org/10.1016/j.bbr.2019.112232

This is a PDF file of an article that has undergone enhancements after acceptance, such as the addition of a cover page and metadata, and formatting for readability, but it is not yet the definitive version of record. This version will undergo additional copyediting, typesetting and review before it is published in its final form, but we are providing this version to give early visibility of the article. Please note that, during the production process, errors may be discovered which could affect the content, and all legal disclaimers that apply to the journal pertain.

(c) 2019 Published by Elsevier. 


\section{Understanding time perception through non-invasive brain stimulation techniques: A review} of studies

\section{Mioni, G. ${ }^{1}$, Grondin, S. ${ }^{2}$ Bardi, L. ${ }^{3}$ \& Stablum, F. ${ }^{1}$}

${ }^{1}$ Dipartimento di Psicologia Generale, Università di Padova, Padova, Italy

${ }^{2}$ École de Psychologie, Université Laval,Québec, Canada

${ }^{3}$ Institut des Sciences Cognitives Marc Jeannerod, UMR 5229, Centre National de la Recherche Scientifique-CNRS, Bron Cedex, France

\section{Corresponding author:}

\section{Giovanna Mioni}

Department of General Psychology

University of Padova

Via Venezia, 12

35131, Padova, Italy

mioni.giovanna@gmail.com

\section{ABSTRACT}

The present review includes transcranial magnetic and transcranial electric stimulation studies on time perception and shows that the neural processing of time requires the activity of wide range-distributed brain networks. Moreover, a critical discussion regarding non-invasive brain stimulation in the study of time processing is included to give the reader insights into the study of temporal processing in neuroscience. The cerebellum and auditory cortex seem most crucial when participants are required to estimate the passage of sub-seconds intervals and this conclusion holds independently of the modality used to mark the temporal intervals. Conversely, the primary visual area and MT/V5 seem to process primarily visual stimuli. The areas included in the prefrontal cortex are mostly implicated in the processing of supra-second time intervals and when time is processed in conjunction with other cognitive functions. Although previous fMRI studies showed activation in the supplementary motor area during sub-second timing tasks, TMS studies failed to confirm these observations. We conclude that the contribution of these strongly interconnected 
structures in the processing of temporal information is not fixed; their contribution depends not only on the duration of the time interval to be assessed by the brain but also on the cognitive set involved in the chosen task and on the stimulus modality used for marking time. Critical observations regarding the specificity of each method of stimulation as well as limitations and criticisms of the studies that used brain stimulation techniques will be also discussed.

KEYWORDS: Time perception, time reproduction, time discrimination, brain stimulation, transcranial magnetic stimulation, transcranial electric stimulation 


\section{Introduction}

Even though time is embedded in many aspects of our life, it remains one of the most elusive problems in psychological research. We cannot approach time as other dimensions like sight, sound or touch, as there are no specific "temporal stimuli" or specific receptors dedicated to temporal processing [1]. Nevertheless, we have some sense of time and certainly some representation of it, and we can efficiently meet the temporal requirements of activities like walking, talking, and playing music. What is even more extraordinary about time is that, unlike other senses, time does not have a specific brain area as other senses do; temporal processing rather relies on the contribution of different brain areas and networks.

One of the most influential models of time processing is the Scalar Expectancy Theory (SET) [2] that is based on an internal clock model [3] in which pulses that are emitted regularly by a pacemaker are temporarily stored in an accumulator. The content of the accumulator provides the raw material for estimating time (clock stage). The outcome from the accumulator is stored in the working memory system for comparison with the content in the reference memory, which contains a long-term memory representation of the number of pulses accumulated on past trials (memory stage). Finally, a decision process compares the current duration values with those in working and reference memory to decide on the adequate temporal response (decision stage). The model has been extensively tested and has the advantage to include the separated stages which makes it possible to map these components onto brain structures.

Despite the success of the SET model in explaining a large set of behavioural and physiological results, its relevance to the brain mechanisms that are involved in timing is still unclear. Therefore, the main interest in the field of temporal processing focused on the identification and the role of brain regions associated with time perception and processing. Various behavioural, neuroimaging and electrophysiological studies have indicated that several brain areas are recruited for temporal processing: the basal ganglia, the cerebellum, the supplementary motor 
area, premotor, parietal and dorsolateral prefrontal cortices [4-10]. Although the role of each of these time regions is still under debate, it is becoming clear that time in different scales is associated with different neural networks and it is sub-served by distinct temporal mechanisms [6] [7].

The first investigations of the biological substrates of the clock and memory stages used pharmacological manipulations and provided considerable support for a dissociation between the clock stage, which is affected by dopaminergic manipulations, and the memory stage, which is affected by cholinergic manipulations $[11,12]$. The connection between the dopaminergic system and the speed of an internal clock has been confirmed by studies with Parkinson's disease who were asked to perform perceptual (i.e., which intervals lasted longer) and motor timing (i.e., continuous tapping) tasks. Parkinson's disease patients showed temporal dysfunction also when low motor component was required [13]. On the other hand, the circuits involving sub-cortical areas with their projections to the prefrontal cortex are mostly implicated in the processing of supra-second time intervals. In fact, a predominant role is related to the prefrontal cortex activity when time intervals have to be kept in memories, with a greater involvement related to longer supra-second time intervals and when the task requires higher cognitive level $[6,9,14,15]$. The parietal cortex seems crucial when time information has to be processed together with spatial information, for both suband supra-second time intervals [16].

Various mechanisms underlying intrinsic models have also been proposed. The most general mechanism assumes that short-term synaptic plasticity, which is at the basis of the dynamics of neural states, can transform the brain networks in timekeepers [17]. According to this view, every cerebral area has the capacity to process and estimate time.

The number of brain regions implicated in timing and the difficulties of studying time perception is indicative of the complexity and behavioural importance of temporal experience in everyday life. One way of identifying areas and networks that are involved in temporal processing is to use non-invasive brain stimulation techniques such as transcranial magnetic stimulation (TMS) 
or transcranial electric stimulation (tES). These techniques have received ample attention in the last decades considering their role in the understanding and modulation of human brain functions; moreover, they offer high spatial and temporal resolution [18]. Therefore, studies with brain stimulation may be particularly important to address the main open question in time processing: how do we perceive and process time? More specifically, is time processed by a unitary mechanism or it is processed by multiple overlapping neural systems? Are there modality-specific and/or modality independent areas involved in timing? What is the role of cognitive functions when processing multiple pieces of temporal information or when we process time in different temporal ranges (sub- and supra-seconds)?

The aim of this work is to critically review the available studies on time processing using non-invasive brain stimulation techniques. Importantly, we focus not only on brain areas involved in temporal processing but also on differences in methodological approaches (temporal tasks, modalities and brain stimulation techniques) to unfold the heterogeneity of studies and the conflicting results. We first describe the different temporal tasks and then the two main noninvasive brain stimulation techniques, namely transcranial magnetic stimulation (TMS) and transcranial electric stimulation (tES), pointing out advantages and disadvantages of each one when employed in temporal studies. A critical discussion of the main areas involved in time processing follows the methodological sections. The discussion is dedicated not only on identifying brain areas and network involved in temporal processing but on considering the future of neuropsychological studies employing non-invasive brain stimulation techniques. This critical work is particularly important considering the crisis of reproducibility that psychological studies are facing recently, in particular in researches that employ non-invasive brain stimulation techniques [19].

\section{Methodological issues in time perception}

\section{Different methods to investigate time perception}


There are two critical taxonomies in the field of timing and temporal processing that may guide the reader: prospective vs. retrospective paradigms, and implicit vs. explicit timing.

We refer to prospective timing or the use of a prospective paradigm, by opposition to a retrospective paradigm when participants know in advance that the duration of a targeted time interval will have to be estimated. When participants are asked to judge time retrospectively, they are unaware that they will be requested to estimate the duration of an activity or of an event; they need to reconstruct the temporal information from memory [20, 21]. As for the other critical distinction, implicit timing is engaged without a specific instruction to time, whenever sensorimotor information can be used to predict the duration of future events (i.e., foreperiods tasks) [22] whereas explicit timing is engaged whenever subjects make a deliberate estimate of the discrete duration in order to compare it with a previously memorised standard [23].

In the present review, we focus on explicit prospective timing, mainly because this is probably the most studied aspect of time processing and also because, as far as we know, no studies have been conducted with non-invasive brain stimulation techniques within the retrospective timing. Few studies have been conducted using TMS to investigate implicit timing (see [24]), but we opted for a more homogeneous pool of studies" (see "Methodological issues" below for further information). Considering that, here we describe the method used in the studies reviewed; please refer to Vatakis and colleagues [25] and Grondin [1,21] for a detailed overview of methods not described here.

Time production. In this task, participants have to produce an interval equal to an interval previously described (i.e., "Produce 2 seconds"). This method involves the comparison of the experienced duration with internal information concerning conventional duration units, such as milliseconds and seconds (i.e., reference memory) [26]. A translation from an objectively labelled

\footnotetext{
${ }^{1}$ See Wiener et al. (2014) for a different organization of the motor and perceptual timing tasks.
} 
duration to a subjectively experienced duration (i.e., time production) has to be completed. Time production is an appropriate way for investigating individual differences related to the internal clock (its speed rate or variables influencing it)[26, 27].

Time reproduction. With this method, participants are required to reproduce the duration of the time interval previously presented. First, participants experience the target duration (i.e., encoding phase), and then they are asked to delimit a time interval (by pressing a designed key) equivalent to the target duration previously presented (i.e., reproduction phase)[27]. This method, which relies on a comparison of previously experienced temporal intervals, might be mainly an index of the consistency of the subjective time experience, providing less information about the variability of the pacemaker rate. Thus, the reproduction method may detect individual differences mainly if it is used in the framework of psychophysical studies, in which duration is varied. In addition, judgments obtained by using the reproduction method (as well as the production method) may be confounded by extraneous variables such as impatience, or the inability to delay a response.

Data collected from the production and time reproduction tasks may be scored in terms of the: (1) relative error $\left(\mathrm{S}_{\mathrm{d}} / \mathrm{O}_{\mathrm{d}}\right),(2)$ absolute error $\left(\left|\mathrm{S}_{\mathrm{d}}-\mathrm{O}_{\mathrm{d}}\right|\right)$, and (3) coefficient of variation $\left(\mathrm{SD} / \mathrm{S}_{\mathrm{d}}\right)$ where $S_{d}$ represents the subjective duration expressed by the participants, $\mathrm{O}_{\mathrm{d}}$ represents the objective target duration presented, and SD, standard deviation, expresses the variability [27]. In computing the $\mathrm{S}_{\mathrm{d}} / \mathrm{O}_{\mathrm{d}}$ ratio, the time estimation is expressed in terms of proportion of physical duration and then the results are comparable across different temporal intervals. The absolute error $\left(\left|\mathrm{S}_{\mathrm{d}}-\mathrm{O}_{\mathrm{d}}\right|\right)$ reflects the magnitude of temporal error without giving any information regarding the duration (i.e., over- or under-estimation). Finally, the coefficient of variation (CV) is an index of temporal variability over a series of trials. Higher variability indicates a reduction in time performance and has been explained as a manifestation of difficulties in maintaining a stable representation of duration. 
Finally, when participants are engaged with time comparison tasks they are required to judge the relative duration of multiple temporal intervals [28]. Within this category falls time discrimination where, typically, participants have to judge the relative duration of intervals presented successively and to indicate, by pressing the appropriate button, whether the second interval was shorter or longer than the first one. One fundamental issue is the measurement of the difference threshold (or difference limen, DL), which provides an estimation of discrimination sensitivity. It is often defined as the minimal physical difference between two stimuli (e.g., $500 \mathrm{~ms}$ vs. $550 \mathrm{~ms}$ interval) necessary for a participant for noticing the difference between them.

There are other methods for comparing time intervals. A classical one, originally developed in animal studies, but adapted to human timing, is time bisection" ${ }^{2}$. With this task, the "standard short" and the "standard long" are first presented several times and are then followed by the presentations of one of several intervals whose duration varies from the short to the long standard values. After each presentation of an interval, participants have to indicate whether it was closer to the short or to the long-standard [29]. With the bisection method, it is possible to draw a psychometric function by plotting the probability of responding "long" on the $y$-axis as a function of the interval value on the $\mathrm{x}$-axis. On this function, the bisection point (BP) in an index of the localization of the bisection criterion, i.e. the stimulus duration at which short/long responses occur with equal frequency, 50\%. An observed shift of the BP can be interpreted as an indicator of differences in perceived time, when experimental conditions are directly compared, with smaller BP values meaning longer perceived durations. Aside from BP, it is also possible to determine the participant's discrimination threshold (or DL, temporal sensitivity), which is essentially indicated by the slope of the function. There are several ways to estimate the DL $[1,21]$, and from this DL, it is possible to calculate the Weber ratio (WR) by dividing the DL by the midpoint value of the

\footnotetext{
${ }^{2}$ Within this category falls also a time generalization task. Since none of the studies included in this review included this task, we decided, for brevity, to exclude it from the description.
} 
standard intervals used to conduct the experiment. Using the WR allows the comparison of time sensitivity at different duration ranges $[30,31]$. A participant with a high degree of temporal sensitivity will have a low DL (and a low WR).

It is critical to evaluate if the stimulation acts on perceived duration (i.e., changing the subjective feeling of the duration of a temporal interval producing a change of the BP) or on temporal sensitivity (i.e. CV or WR). These considerations are of fundamental interest for a correct interpretation of the effects of stimulation on temporal processing and to evaluate the brain areas and circuits involved in temporal processing.

\section{Modality and temporal ranges}

Even though there are no sensory organs specifically dedicated to time perception, it is possible to process durations within various sensory modalities (auditory, visual, and tactile). This ability to integrate multisensory information over time is fundamental for developing a coherent perception of the world and to adapt behaviour to the multiple environmental changes [32]. However, although time perception seems to be independent of any specific sensory modality different data lead to moderate this assumption. Indeed, some behavioural [33, 34] and electrophysiological [35] studies indicated that the ability to process durations is influenced by the sensory input. It has been shown that temporal intervals are judged as longer when marked by auditory rather than by visual stimuli. In addition, different data have revealed that sensitivity to time is better (lower variability) in the auditory rather than visual modality, a finding that applies to both filled and empty intervals [21].

A general tendency in timing literature is to emphasize a distinction between intervals above and below1s, which is based on differential pharmacological effects $[11,12]$ and on patient studies with various brain damages $[14,15,36,37]$. Moreover, researchers claimed that the processing of shorter intervals is more sensory based, or benefits from some automatic processing, whereas the processing of longer intervals requires the support of cognitive resources [38]. Even if this "1-s" 
transition period remains somewhat arbitrary, there is certainly some turning point on the time continuum given the benefit one should expect from adopting an explicit counting strategy for processing long temporal intervals [39-41]. Indeed, there are empirical reasons to believe that this transition occurs circa $1.2 \mathrm{~s}$ at least for the processing of auditory time intervals, the Weber fraction for time increasing for intervals longer than about 1.3-1.5 s [30, 31]. Recently, Nani and colleagues in their meta-analysis of fMRI studies [10] confirmed that both subsecond and suprasecond tasks recruit cortical and subcortical areas, but subcortical areas contribute more to the pattern associated with subsecond intervals than to the pattern associated with suprasecond intervals, which instead receives more contributions from cortical activations. This is in line with the idea that distinct timing mechanisms may operate at different timescales [42], as well as to the idea that intervals below the 1-sec range are supposed to be more dependent on sensory and automatic processes, whereas the detection and estimation of intervals longer than 1-sec are thought to rely more on cognitive functions $[12,37,38,43]$.

\section{Transcranial magnetic stimulation and transcranial electric stimulation techniques}

Brain stimulation techniques are widely used in neuroscience research. The most important feature of these methods is that they allow non-invasively intervening (e.g., excitation or inhibition) on neural tissues through the skull, so that causal inferences can be made about the role of a cortical area in cognitive functions or tasks $[44,45]$. Two methods are the most known and commonly used: transcranial magnetic stimulation (TMS; Figure 1), and transcranial electric stimulation (tES; Figure 1) $[46,47]$.

\section{Transcranial magnetic stimulation}

Transcranial magnetic stimulation (TMS) involves delivering a brief magnetic field through a stimulation coil to the human scalp. The rapidly changing magnetic field generates, for the principles of electromagnetic induction, a transitory electric current in the underlying neural tissue 
causing depolarization of a neuronal population [48]. The effect of TMS has been characterized at the physiological level mostly by the use of electromyography (EMG). When TMS is applied to the primary motor cortex, a muscle twitch is produced in the contralateral hand, via depolarisation of the neurons of the corticospinal tract. The amplitude of the motor-evoked potential (MEP) recorded from the limb, reflects the level of excitability of the corticospinal system. Beyond stimulation of the primary motor (and visual) cortex, however, the physiological mechanisms underlying the effects observed in cognitive tasks remain not fully understood. Some authors proposed that TMS effects can be conceptualized as "neural noise". Since the stimulation induces action potentials that are not directly associated with the ongoing neural activity, its effect may depend upon the specific signal/noise relationship in the neural population at a specific point. This can result in both positive (facilitation) and negative (interference) behavioral outcomes [49]. In any case, TMS effects can vary depending on the intensity, frequency and duration of stimulation, and the current state of the targeted region.

The most common stimulation protocols include 'single-pulse' stimulation, 'paired-pulse' TMS, standard repetitive TMS (rTMS) and patterned TMS (e.g., Theta-burst stimulation-TBS) [50]. TMS may be administrated "on-line" or "off-line": In the first setting, TMS (single-pulse, pairedpulse or rTMS) is applied during task execution and participant's performance during stimulation is compared with a sham condition or with performance during stimulation of a control area (i.e., area not expected to be involved in time processing) whereas in the latter (rTMS or TBS), the participant's performance is compared before and after stimulation. With "on-line" paradigms, TMS can induce interference in a specific time window in which the cognitive process of interest takes place. The duration of the effect produced by a single TMS pulse is in the order of milliseconds. This is particularly interesting in those tasks in which it is possible to distinguish between encoding and production phase (time reproduction task) or in which two temporal intervals are compared (time discrimination task). With "off-line" protocols, repetitive TMS can lead to 
synaptic plasticity, long-term potentiation (LTP)- and long-term depression (LTD)-like

mechanisms, resulting in a modulation of cortical excitability that may last several minutes to about 1 hour after stimulation. With low-frequency TMS, a series of pulses with a frequency $\leq 1 \mathrm{~Hz}$ (e.g., for 15 minutes) is thought to suppress cortical excitability $[50,51]$ although it may not always cause inhibitory effects [52]. On the other hand, higher frequency TMS (> 1 Hz) is expected to have facilitatory effects. TBS is also able to cause lasting physiological changes after short stimulation durations, and its effects may exceed those of standard rTMS. The advantage of TBS is that a relatively large number of pulses can be delivered in short time $[45,53]$. With continuous TBS (cTBS), 3 pulses of stimulation are given at $50 \mathrm{~Hz}$, repeated every $200 \mathrm{~ms}(5 \mathrm{~Hz})$, typically for $40 \mathrm{~s}$, for a total of 600 pulses. CTBS may result in inhibitory after-effects. With intermittent TBS (iTBS) a $2 \mathrm{~s}$ train of TBS is repeated every $10 \mathrm{~s}$, resulting in facilitatory after-effects [54]. When singlepulse TMS of the motor cortex is used to probe the effect of TBS, continuous stimulation results in a reduction of MEPs amplitude, while intermittent TBS leads to an increase of MEPs amplitude [55]. Finally, other TMS protocols that can be defined as "patterned" are quadripulse TMS [56] paired associative stimulation (PAS [57]) and cortico-cortical paired associative stimulation (ccPAS, [58]) which allow the study of brain connectivity mechanisms. With ccPAS, TMS pulses are contingently and repeatedly delivered to distal cortical regions (e.g., frontal and parietal cortices) to modulate the synaptic strength of neural connections [58].

The spatial resolution of TMS, which depends on the stimulation parameters, the shape of the stimulation coil, and the target area, has been estimated in the order of $\sim 1-2 \mathrm{~cm}^{2}$ [59] or less [60, 61]. However, studies combining different neuroimaging methods (e.g., TMS-EEG) revealed that the stimulation spreads trans-synaptically over connected areas [62-64]. Therefore, beyond its direct effects (those induced in the neural tissue directly affected by the magnetic field), TMS has indirect effects, which limits its focality. 
While the relatively high temporal resolution of on-line TMS is of great interest for the study of time processing, TMS also has many disadvantages, which include the sound and the sensation emitted during the stimulation. A number of studies have previously reported that the presentation of a rapid series of auditory clicks alone is capable of leading to the subjective lengthening of perceived duration, possibly by increasing arousal, thereby increasing the speed of the pacemaker [65-67]. Moreover, some aversive sensations may be reported during TMS [47]. These limitations are overpassed by transcranial electric stimulation techniques, which, on the other hand, have other limitations.

[Figure 1 about here]

\section{Transcranial electric stimulation}

These techniques deliver a weak electrical current through two scalp electrodes by a portable battery-powered stimulator to induce a temporary modulation of the cortical excitability. The low-intensity electrical field generated by electrical stimulation is subthreshold, and not changing rapidly enough to induce action potentials in resting neurons. It is capable of modifying neuronal transmembrane potentials, therefore modulating spontaneous firing rates. Three types of electric stimulation can be used depending on the type of current delivered: transcranial direct current stimulation (tDCS), transcranial random noise stimulation (tRNS) and transcranial alternating current stimulation (tACS). In all cases, two electrodes are placed over the scalp with current delivered normally between 1 and $2 \mathrm{~mA}[46,68,69]$.

tDCS effects depend on polarity; cathodal stimulation leads to hyperpolarization and, consequently, to inhibition, while anodal stimulation causes the resting membrane potential to become more positive and, therefore, it results in facilitation. However, these effects do not appear to be consistent across studies. Indeed, this distinction is confirmed especially by studies on motor function $[70,71]$ : using anodal tDCS over the motor cortex increases the amplitude of TMS-evoked MEPs and using cathodal tDCS decreases MEPs amplitude. 
Outside the motor system, there is no necessary correspondence between excitation/inhibition and behavioural improvements/impairments, since the timing of stimulation, the excitability status of the cortical area and the type of task, among others, can influence the outcome $[72,73]$.

tRNS and tACS are highly effective methods for avoiding directional sensitivity of standard tDCS; with tRNS, the frequency of the current varies in a random manner changing within a spectrum of oscillations ranging from $0.1 \mathrm{~Hz}$ to $640 \mathrm{~Hz}$, whereas, tACS uses a sinusoidal current that allows manipulation of intrinsic cortical oscillations $[46,69]$. tACS is not intended to excite or inhibit cortical activity monotonously but the main goal of tACS is to influence brain oscillations [74].

Potential effects of tES might be related to the improvement of the signal-to-noise ratio in the central nervous system and to the sensitization of sensory processing $[75,76]$. It was suggested that tRNS and tACS may increase synchronization of neural firing through amplification of subthreshold oscillatory activity, which in turn reduces the amount of endogenous noise [75]. Therefore, the effects of tRNS might be based on mechanisms such as stochastic resonance [77, 78]. tRNS after-effects are intensity-dependent; stimulation at $1.5 \mathrm{~mA}$ leading to excitability after-effect is comparable to what has been observed with anodal tDCS, whereas a lower intensity (0.4 mA) leads to inhibitory after-effect comparable with cathodal tDCS [79, 80]. Terney et al. [81] reported that tRNS induces cortical excitability increases lasting $60 \mathrm{~min}$ after stimulation. Moreover, tACS applied with a frequency of $140 \mathrm{~Hz}$, the so-called 'ripple frequency', has been shown to increase excitability in a similar way to both anodal tDCS and tRNS [80]. Interestingly, the after-effects of tRNS and tACS are intensity dependent. Intensity stimulation at $1.0 \mathrm{~mA}$ tRNS or tACS leads to excitability after-effects that are comparable to what has been observed with anodal tDCS. However, the lower intensity at $0.4 \mathrm{~mA}$ tRNS or tACS leads to inhibitory after-effects comparable to those observed with cathodal tDCS [80]. 
Few studies have been conducted to directly compare efficacy in cortical excitability alteration and tRNS resulted in the largest significant increase in motor evoked potentials (MEPs), suggesting that tRNS is the most effective tES method [79, 82, 83]. Interestingly, less sensory sensations are reported during tRNS and tACS, compared to tDCS [84]. Therefore, the application of tRNS might be better suited for placebo-controlled studies [82, 85].

\section{Methods}

\section{Studies selection}

A computer-based search involving PsycInfo, PubMed and Web of Science was conducted up to February 2019 using the terms: “Time perception”, “time processing”, “time reproduction”, "time production", "time discrimination", "time bisection", "brain areas", "transcranial magnetic stimulation", "transcranial electric stimulation" (tDCS, tRNS and tACS). In addition, reference lists from published reviews, books, and chapters were checked to identify studies that may not have been found when searching on databases. The research was conducted independently by the first author and by the library assistant at the Department of General Psychology, Padova University (Italy). To be included in the systematic review studies have to meet the following inclusion criteria:

- to use transcranial magnetic stimulation

- to use transcranial electric stimulation such as tDCS, tRNS and/or tACS

- to use prospective and explicit timing tasks

- to include healthy participants

\section{Systematic review}

The literature screening and final selection have been performed according to the PRISMA guidelines [86]. This procedure is summarized in the PRISMA flow diagram (Table 1 Supplementary materials). The research methods resulted in a combined total of 262 published 
articles. The abstracts and full paper were reviewed independently by the authors GM and FS to eliminate articles according to the following exclusion criteria: review articles; papers that included patients (i.e., Parkinson's or Alzheimer's disease) or any other cognitive impairment (i.e., aphasia); children and studies that used implicit timing tasks (i.e., foreperiod tasks)[24]. Importantly, we also excluded studies that tested a combination of time, space and number in which it was not possible to isolate time performance [87]. Applying the PRISMA procedure, a total of 27 original articles were found eligible to be included in the systematic review (Table 1 Supplementary materials). The authors GM and FS and a colleague (PT, in the acknowledgements) extracted and checked the data independently.

\section{TMS and tES studies of time processing}

\section{Cerebellum}

The importance of the cerebellum in timing is well documented, in particular in tasks that require motor behaviour with a strong temporal aspect [88-91]. Recently, Breska and Ivry [92] documented a double dissociation in patients with cerebellar degeneration and Parkinson's patients providing causal evidence for functionally non-overlapping mechanisms of rhythm and singleinterval temporal prediction for attentional orienting. Patients with cerebellar damage exhibit increased temporal variability both in producing timed movements and in discriminating durations. Therefore, cerebellar patients perform poorly even in those tasks in which they are required to estimate certain durations without necessarily performing movement.

Table 1 summarises the TMS studies targeting cerebellum. The studies included visual $(n=2)$, auditory $(n=4)$ and tactile $(n=1)$ modalities as well as both sub- $(n=7)$ and supra-second intervals $(\mathrm{n}=4)$. Koch et al. [93] reported in two studies that rTMS (offline at $1 \mathrm{~Hz}$ for $10 \mathrm{~min}$; visual modality) selectively disrupted subject's performance (perceived duration) for the sub-second (500 ms) but not supra-seconds time intervals when rTMS was applied over the left side 
(Experiment 1). In Experiment 2, the authors extended these findings reporting an overreproduction only when stimulation $(20 \mathrm{~Hz})$ was applied during the encoding phase. Similarly, Lee and colleagues [94], using auditory stimuli, showed temporal over-estimation for sub-second (400 $800 \mathrm{~ms}$ ) intervals when rTMS was applied over medial cerebellum (1 Hz for $8 \mathrm{~min}$ ). Both Koch et al. [93] and Lee et al. [94] included also supra-second intervals (2000 ms and 1000-2000 ms, respectively) and showed an absence of cerebellar involvement in the perception of supra-second time intervals. Only Grube et al. [95] used an online procedure with theta-burst TMS (20-ms intervals at $5 \mathrm{~Hz}$ repeated every $200 \mathrm{~ms}$ ) with auditory stimuli. Their results showed a higher discrimination threshold (lower performance level) in sub-seconds intervals (300-600 ms). Finally, Fierro et al. [96] used tactile stimuli with sub-second intervals (300-500 ms) and showed worsened temporal discrimination with rTMS applied over the right side (1 Hz, $15 \mathrm{~min})$. All studies besides Gironell et al. [97] reported variations in time processing. It is important to note that Gironell and colleagues [97] used very long intervals $(180 \mathrm{~s} ; 5 \mathrm{~Hz})$ and temporal misperceptions in patients with cerebellar disorder are normally conducted with sub-second intervals [88-92, 98]. The results of these studies are in line with the proposal that different neural systems are involved in sub- and supra-second timing, with the former mainly subserved by the cerebellum [94].

The involvement of the cerebellum in sub-seconds timing is confirmed in previous TMS studies, but the specific role of each hemilateral part of it remains to be determined. A previous review of TMS studies [99] reported a preferential involvement of the right cerebellum in subsecond timing, with left hemisphere involvement being inconsistently noted. However, some patients' studies suggest that temporal impairment is more pronounced in patients with left cerebellar damage than in patients with right cerebellar damage [88, 92, 100, 101]. Wiener et al. [9] showed bilateral activation in the posterior cerebellum. As far as we know, after 2007, no studies have been conducted testing the involvement of the cerebellum in explicit timing; therefore; the 
results are still mixed with some studies reporting compromised time processing after right $[94,96]$, left [93], medial [94, 95] or bilateral [93] TMS and more studies should be conducted.

Interestingly, TMS over cerebellum seems to affect perceived duration rather than temporal variability. The findings of Koch et al. [93] showed that the cerebellum is involved in the initial encoding phase of a stimulus, but not during its subsequent reproduction; cerebellar involvement in encoding may suggest a role in clock functioning, but the clock-stage is also involved during the reproduction phase, therefore with regards to scalar timing theory, the mechanistic role of the cerebellum cannot be stated with certainty [102].

[Table 1 about here]

\section{Occipital cortex}

Table 2 summarizes the studies that investigated the role of occipital cortex in time processing with TMS. Three studies are included and all reported modality-dependent activation of different occipital cortical areas; more specifically, higher discrimination threshold and higher variability were observed.

Bueti et al. [103] and Kanai et al. [104] included both visual and auditory stimuli, demonstrating with TMS that the extrastriate visual cortex (V5/MT) and the primary visual cortex are selectively involved in processing visual stimuli. All the studies that targeted occipital cortex employed time discrimination task with sub-second intervals, giving more methodological consistency across studies. Kanai et al. [104] was the only study using an offline procedure with theta-burst TMS $(50 \mathrm{~Hz})$ whereas Bueti et al. [103] and Salvioni et al. [105] opted for an online procedure that gave the authors the possibility to specifically target the standard or the comparison interval. Bueti et al. [103] applied 12-Hz stimulation for $500 \mathrm{~ms}$ at the onset of the comparison interval whereas Salvioni et al. [105] applied paired-pulse TMS at the onset of the standard 
(Experiment 1) to test the involvement in encoding time, and at offset of standard (Experiment 2) to control for the involvement of occipital area during the retention period.

Interestingly, Table 6 reports studies with electric stimulations. In particular, Mioni et al. [106] and Mioni [107] targeted V1 with tDCS and tRNS, respectively, and both studies confirmed a modality-specific role of V1 in temporal processing. Moreover, in both studies employing electric stimulations, we observed a different effect of stimulation on perceived duration: cathodal tDCS increased temporal variability, whereas tRNS affected perceived duration causing a temporal overestimation.

Taken together, these studies showed that stimulating both V1 and MT/V5 close to the end of the visual standard interval increased variability. Furthermore, stimulating V1 increased variability only when applied early in the retention interval, whereas stimulating MT/V5 disrupted performance only when it occurred in the middle of the retention interval. These findings suggest an involvement of the occipital cortex in timing that goes beyond simple stimulus encoding as previous research suggested that V1 neurons may learn to encode temporal expectancies [108]. Interestingly, the results of Salvioni and colleagues [105] showed different involvement of V1 and MT/V5 at different perceptual levels, which warrants further investigation. Additional tasks and duration lengths should also be explored with occipital stimulation, in order to determine if the results of the above-mentioned studies are due to task-specific effects (sub-second, perceptual) or to domain-general processes.

[Table 2 about here]

\section{Temporal cortex}

Table 3 summarises the four studies that investigated the contribution of temporal cortex in timing. All tested the contribution of auditory areas, in particular, the right superior temporal gyrus 
(STG) in temporal processing, following previous findings reporting selectively right-side activation during timing tasks [109]. All studies beside Giovannelli et al. [110] used sub-second intervals; Bueti et al. [111], Giovannelli et al. [110] and Kanai et al. [104] used auditory and/or visual stimuli whereas Bolognini et al. [112] was the only study employing tactile stimuli. Bueti et al. (online, $10 \mathrm{~Hz}$ ) [111] showed lower accuracy after right STG stimulation; the results were further extended by Kanai et al. [104] showing higher discrimination threshold when targeting (offline theta-burst) the primary auditory cortex for both auditory and visual stimuli. Their findings first suggested that STG might play an important, supramodal role in temporal processing. These conclusions were also supported by Mioni et al. [106] who targeted primary auditory cortex with online tDCS (Table 6). Results showed higher temporal variability under anodal and cathodal stimulation independently of the modality (visual or auditory) used for marking intervals.

Bolognini et al. [112] used a tactile time discrimination task with single-pulse TMS (offline) and showed a temporal disruption when TMS was applied over the left STG $180 \mathrm{~ms}$ after the tactile presentation. The authors also concluded that there is a causal involvement of the auditory areas in the processing of the duration of somatosensory events, suggesting that the role of the STG is not limited to the processing of auditory material. However, the results provided by Giovannelli et al. [110] go in a different direction; in fact, these authors failed to report an effect of rTMS in time discrimination (same localization as in Bueti et al., [111]). One important difference is the temporal range employed; in fact, Giovannelli et al. [110] used auditory stimuli between 800 and $1200 \mathrm{~ms}$ whereas Bueti et al. [111] and Kanai et al. [104] used durations below 1s (around $600 \mathrm{ms).}$

One hypothesis for the modality-independent role of STG in timing could be that inputs from other sensory modalities (visual or tactile) are automatically converted to an auditory representation when its duration is estimated. Although this hypothesis needs further support, it is in line with a previous study showing that time estimation is mediated by phonological working memory [113]. Since the phonological loop is supported by bilateral auditory cortex and inferior 
frontal gyrus [114], it seems plausible that a disruption of a part of the network supporting phonological working memory impairs time perception whatever the sensory modality used to mark time. Altogether these studies seem to support the hypothesis that the auditory cortex is involved in somatosensory processing and also that multisensory integration occurs at an early stage of temporal processing.

[Table 3 about here]

\section{Frontal cortex}

Table 4 reports the studies that investigated the contribution of frontal cortex in timing. A first interesting consideration is that in 7 experiments across 6 studies, all except one [110] used a time reproduction or time production tasks with supra-second intervals. This consistency is probably the first intriguing finding in line with the idea that frontal areas are involved in temporal processing, mainly when supra-second intervals have to be processed. However, the temporal misperception observed in these studies is probably due to a disruption of other cognitive functions (attention and working memory) involved in the task rather than due to a genuine temporal impairment [37]. This hypothesis is in line with the idea that separate neural timing systems are recruited when intervals from different temporal ranges (sub- and supra-second) have to be processed. Lewis and Miall [38] distinguished between an 'automatic' system drawing mainly upon motor circuits (sub-second) and a 'cognitively controlled' system (supra-second) that would depend upon prefrontal and parietal regions.

Koch and colleagues [115] first targeted (1 Hz offline) the dorsolateral prefrontal cortex (DLPFC) and observed an under-reproduction of supra-second intervals, but this happened only following a right DLPFC stimulation. Jones et al. [116] replicated this effect (brief trains of $20 \mathrm{~Hz}$ rTMS, online); crucially, the effect only occurred for supra-second intervals and when stimulation 
occurred during reproduction, not during the encoding phase. However, Koch et al. [93] observed temporal over-reproduction of supra-second temporal intervals (offline $1 \mathrm{~Hz}$ ) when the stimulation was applied over the right DLPFC. Gironell et al. [97] also targeted the right and left DLPFC with 5-Hz stimulation in trains of $10 \mathrm{~s}$ with an inter-stimulus interval of $30 \mathrm{~s}$ (online); their participants had to perform a 180-sec interval production task. Surprisingly, no effect of stimulation was observed but this result might be explained by task characteristics. In fact, time reproduction task recruits higher-order cognitive functions (e.g., attention, working memory, executive function) to keep active the reference duration in order to subsequently reproduce them). Conversely, the time production task used by Gironell et al. [97] may require less involvement of attentional, working memory and executive function abilities (see "Different methods to investigate time perception" section, above). Moreover, it is important to note that in Gironell's et al. [97] study, participants were asked to internally count during the production of time intervals and this may have helped participants performing the task [117].

These studies suggest that the right DLPFC plays a role in temporal processing when suprasecond intervals are employed and in particular in the reproduction phase [116] that requires reactivating previously stored temporal information. This is also consistent with Mioni et al. [118]'s findings reported in Table 6. The authors used sub-second intervals marked with visual and auditory stimuli and showed no effect of tRNS over the DLPFC (F4), confirming the role of right frontal areas in supra-second processing.

However, inconsistencies persist with respect to the direction of the TMS effects over DLPFC, which might be explained by methodological differences between the studies. Koch et al. [93] found temporal over-reproduction while Jones et al. [116] found temporal under-reproduction with temporal intervals within the same temporal range (500-2000ms; see Table 4). However, in the first study, the authors used filled visual stimuli, while in the latter, the authors used empty visual stimuli. Interestingly, Santi and colleagues [119] showed that rats made more long responses 
for filled than for empty intervals, suggesting a lengthening effect of filled intervals and confirming the different over- and under-reproduction observed by Koch et al. [93] and Jones et al. [116] ${ }^{3}$. Moreover, in another study, Koch et al. [115] used longer temporal intervals (5-15 sec) and also asked participants to perform a concurrent non-temporal task during the encoding and reproduction phases, i.e., read random digit aloud. The inclusion of a concurrent secondary task might have reduced attentional resources dedicated to time, causing temporal under-reproductions [20, 21]. This hypothesis, which would explain the over- and under-reproductions observed by Koch et al. [93] and Koch et al. [115], is consistent with the Attentional gate model [120]: when less attention is allocated to time, less temporal information is stored in the accumulator and the temporal interval is judged to be shorter than the reference duration.

Three studies also tested the supplementary motor area (SMA) but did not find any effect of stimulation on perceived duration, Dusek et al. [121] observed reduced variability at $10 \mathrm{~s}$ only, whereas Giovannelli et al. [110] found slightly faster reaction time following rTMS but irrespectively of area of stimulation (the authors tested also parietal and temporal cortices, see Tables 3 and 5). This finding may be surprising, as the SMA is the most commonly activated region across neuroimaging studies of time perception in every task context $[9,122]$; moreover, a recent study by Protopapa and collaborators [123] showed that SMA's neural units tuned to different durations and that are mapped in contiguous portions of the cortical surface so as to form chronomaps. One possible explanation is that timing-sensitive regions of the SMA may lie within deeper layers of the cortex that the TMS pulse cannot penetrate down to. In addition, based on recent evidence [123], SMA may be functionally divided into pre-SMA and SMA, an issue that was never considered in previous TMS studies. In fact, Wiener [99] commented that the pre-SMA is

\footnotetext{
${ }^{3}$ For an analysis of the potential impact of using filled vs. empty intervals, see Grondin (2003).
} 
more likely to be activated in perceptual studies of timing, whereas the SMA proper is more commonly found in motor timing studies [9].

[Table 4 about here]

\section{Parietal cortex}

Table 5 and Table 6 summarise the studies conducted with TMS and tES that investigated the contribution of parietal cortex in timing. A preliminary consideration relates to the fact that the majority of studies using non-invasive brain stimulation techniques have been targeting this area and confirming the well-known involvement of parietal areas in timing. The role of the parietal cortex in temporal processing has been observed in previous fMRI [124-126] and electrophysiological studies [35]; interestingly, the parietal cortex is considered a multimodal region [103] as it is involved in multisensory integration [127, 128].

\section{$\underline{\text { TMS studies }}$}

In line with the idea that the parietal cortex is multimodal region, Bueti et al. [103] stimulated (12 Hz; online procedure) the left and right inferior parietal cortex (IPC, angular gyrus AG) with auditory and visual stimuli using a time discrimination task (600-ms standard). The authors demonstrated a supramodal role of the right AG, with increased variability for both auditory and visual temporal discrimination tasks following stimulation occurring at the comparison stimulus onset. Within the papers that used only auditory stimuli, Alexander et al. [129] targeted the left and right IPC (AG) with offline $1 \mathrm{~Hz}$ stimulation. Participants' performance was weakly affected by TMS (increased reaction time, but no change in variability or accuracy) after a right stimulation. Similarly, Giovannelli et al. [110] used a time discrimination task with supra-second intervals (1 $\mathrm{Hz}$ ) and observed higher reaction time after right TMS stimulation. Only Riemer et al. [130] (time 
discrimination; supra-second intervals) showed increased variability (DL) but no effect on perceived duration (PSE) or reaction time after theta-burst stimulation.

Considering the studies that used visual stimuli and time discrimination tasks, Dormal et al. [131], who worked with sub-second intervals, showed no effect of offline TMS (1 Hz $15 \mathrm{~min})$ after left and right sides stimulation. In two more studies, Wiener et al. [132, 133] stimulated the supramarginal gyrus (SMG) of the inferior parietal lobe. The authors demonstrated that right, but not left, SMG stimulation (online, $10 \mathrm{~Hz}$ ) induced a significant variation in perceived duration [132]. Specifically, the rTMS effect was in the opposite direction in the two experiments presented. Whereas rTMS during the standard stimulus in Experiment1 led to a decrease in the proportion of trials in which subjects indicated the standard (first) stimulus was longer, rTMS during the comparison stimulus led to an increase in the proportion of trials in which subjects indicated that the comparison (second) stimulus was longer (Experiment 2). Furthermore, Wiener et al. [133] replicated this lengthening effect using rTMS $(10 \mathrm{~Hz})$ over the right SMG. Stimulation of the right SMG seems to selectively increase perceived duration, as this increase occurred during stimulation of either the standard (first) or comparison (second) stimulus. Any disruption of the mechanisms involved in memory or decisional processing would probably not help explaining the results.

A group of studies also used time reproduction tasks with supra-second intervals. Oliveri et al. [134] (Experiment 1) showed that the inhibition of the right IPC (AG) caused by rTMS (1 Hz for $10 \mathrm{~min}$ ) induces a directional bias with subjects under-producing half of a time interval (time reproduction - half reproduction ${ }^{4}$ ). Moreover, in Experiment 3 of the same study, the authors showed that the under-reproduction of bisected ${ }^{5}$ interval, following rTMS on the right IPC, was specifically observed when rTMS trains were delivered online during the retrieval phase of the time reproduction task. The authors speculated that the PPC becomes critical when timing requires the

\footnotetext{
${ }^{4}$ See note 1 on Table 5

${ }^{5}$ See note 1 on Table 5
} 
integration of spatial processes (see also [16]), as when participants are required to reproduce half of the encoded interval. A disruption of the right PPC could cause temporal neglect while subjects are retrieving half of a previously encoded time interval. This might mimic the rightward error made in line bisection tasks by patients with hemispatial neglect following right-brain-damage, or when healthy subjects receive rTMS on the right IPC (Experiments 2 and 4[134]). Finally, Dusek et al. [121] showed increased variability after theta-burst stimulation of precuneus but only for $5 \mathrm{sec}$ intervals, whereas and Rocha et al. [135] showed higher accuracy after rTMS (offline, $1 \mathrm{~Hz} 15 \mathrm{~min}$ ) over the superior parietal cortex (Pz electrode correspondence 10/20 EEG system), but only at 4 and 9 sec.

\section{$\underline{t E S \text { studies }}$}

Within the tES studies that used electric stimulations over the parietal cortex, all except Mioni et al. [118] used tDCS (anodal/cathodal) with visual stimuli with both visual and auditory stimuli. Vicario et al. [136] and Mioni et al. [118] used an extracephalic montage, Javadi et al.[137] used a bilateral montage (P3/P4) and Oyama [138] positioned the reference electrode over the contralateral supraorbital area.

Taking advantage of the different effects of anodal and cathodal stimulations, Vicario et al. [136] and Javadi et al. [137] investigated the different involvements of left and right PPC in timing. Vicario et al. [136] showed that cathodal stimulation over the right PPC affected temporal accuracy by leading participants to over-reproduce time intervals; when the cathodal stimulation applied to the left PPC, it reduced the variability when reproducing temporal intervals. Javadi et al. [137] showed that application of anodal tDCS to the left-PPC and cathodal tDCS to the right-PPC impaired temporal accuracy in the time discrimination task, while application of anodal tDCS to the right-PPC and cathodal tDCS to the left-PPC increased accuracy in the duration judgment task. Finally, Oyama et al. [138] and Mioni et al. [118] only targeted the right PPC and observed improved temporal discrimination after cathodal stimulation and a lengthening effect after tRNS 
stimulation. Direct comparisons between these studies are difficult considering the methodological differences. Nevertheless, what can be said is that left and right PPC seem to play different roles in temporal processing, with more critical involvement of the right side.

[Tables 5 and 6 about here]

\section{Discussion}

Many cortical (parietal, premotor, and prefrontal) and subcortical (basal ganglia and cerebellum) brain structures have been reported to be implicated in the processing of temporal information and this, independently from the sensory modality of the stimuli marking time intervals $[9,14,15]$. Although there is only a partial agreement regarding the relevance of all these structures to time processing, the challenge is to explore whether these areas have dissociable or interchangeable/overlapping functional roles and therefore whether these areas support the same or different temporal mechanisms.

Wiener et al. [99] conducted an interesting review of TMS studies and concluded it with important remarks regarding future TMS studies. For example, setting task difficulties based on the participant's level can elucidate effects that may not otherwise be apparent (intra-subjects variability). Also, site selection requires great care; some studies localised the targeted areas based on individual fMRI whereas others used group imaging. The authors concluded their work with suggestions for future studies, including among others the use of theta burst stimulation to induce both excitatory and inhibitory effects or to investigate the combination of TMS with other methodologies (see [139] for new insights on co-registration).

The number of studies using TMS has not increased much recently, but new non-invasive brain stimulation techniques have been employed in the study of time processing. What is ironic is that the alternative tool selected, the tES has some technical advantages (less noise and less 
sensation reported), but, also some disadvantages (poor spatial and temporal resolution). Moreover, the expected facilitatory-like effect, with anodic stimulation, and inhibitory-like effect, with cathodal stimulation, are hardly observed with cognitive tasks as it is within the motor domain [72, $73,140]$. Although several studies revealed an effect of tDCS over cognitive functioning, there is no systematic correspondence between the anodal-excitation and cathodal-inhibition effects since several important factors such as the timing of stimulation, the excitability status of the underlying cortical tissue, the site of application, and the type of task, all have a critical role in determining the outcome of this stimulation procedure $[46,69,79]$.

Despite that, the new studies moved forward the understanding of the organization of brain areas in temporal processing. Cerebellum and occipital areas seem to be mainly involved when subsecond intervals are employed (Tables 1 and 2). With regards to the scalar timing theory, can we consider these areas as part of the internal clock functioning? The majority of studies showed an effect of TMS on perceived duration, suggesting an effect at the internal clock level rather than at the memory or decisional stage. If the cerebellum seems to be involved independently of the stimulus modality, a clear modality-specific role of the occipital cortex emerged from the present review of the literature. However, more studies need to be conducted in particular to investigate the role of the primary visual area in time processing since very few studies have been conducted so far and any TMS effect on visual time perception could be due to disruption of incoming signals.

The auditory cortex and, in particular, the superior temporal gyrus, seems to be a multimodal area involved in sub-second temporal processing. In fact, temporal misperception was observed with/after TMS on visual, auditory and tactile stimuli, with a greater effect on perceived duration but also on temporal variability. The supra-modal involvement of auditory areas in temporal tasks has been associated with a strategic use of auditory-based mental representations for time estimation. A speculation originally proposed by Kanai et al. [104] is that visual information is converted into an auditory code for temporal computation. This hypothesis is interesting because it 
offers an insight into the relationship between visual and auditory timing systems and highlights a possible link between modality independent and modality-specific temporal mechanisms.

The more puzzling findings emerge from the studies that targeted the parietal cortex. Again it seems that this area, in particular, the right angular gyrus, is involved in the multi-modal processing of sub-second intervals [16, 103]. However, Oliveri et al. [134] showed involvement of this area also in supra-second temporal processing (only visual stimuli), specifically during the reproduction phase of an interval reproduction task. The authors concluded that the angular gyrus has a crucial role in the "when pathway" of the brain; in addition, their results with a spatial bisection task led the authors to conclude that this region becomes critical in timing when time processing requires the integration with spatial processes. It has been shown that the angular gyrus plays a role in switching attention and allocating attentional resources [15] and attention to action with a strong spatial component $[141,142]$. Following the distinction between "motor" and "perceptual" $[9,10]$, the parietal cortex and subcortical areas seem to be activated more extensively with "motor" than "perceptual" timing for their rule in building spatio-temporal representations and then voluntary orienting motor responses $[10,134]$. Also, the parietal cortex processes other magnitude features, including size and number. It is, therefore, possible that an approximate timing system, similar to numerical-tuned responses, also exists within this region[16].

More consistency across studies comes from the stimulation of the frontal area. Taken together, the studies targeting the frontal area show an involvement of the right DLPFC in suprasecond processing (Table 4). This is in line with studies with frontal patients suggesting that temporal impairment in these patients is related to the deficits in cognitive functions involved in temporal processing such as working memory, attention and executive functions, rather than to impairment in time estimation per se [37]. Despite a variety of fMRI studies [9, 10, 122] showing activation of SMA in both perceptual and sensory-motor processing of temporal intervals, the data from TMS studies did not confirm these findings. As stated above, one possible explanation is that 
timing-sensitive regions of the SMA may lie within deeper layers of the cortex that the TMS pulse cannot penetrate. Future studies should be conducted in particular in line with a recent review of fMRI studies [10].

Overall, it seems likely that a wide range-distributed neural network is useful to process time information, with a prevalent involvement of specific structures that depends not only on the duration of the time interval to be assessed by the brain but also on the task adopted and the modality of the stimulus marking time. The hypothesis that timing may be mediated by multiple distinct procedures also accounts for the lack of neurologic disorders characterized by a profound and selective impairment in temporal processing [14, 37, 98].

The present review adds to previous works $[9,98]$ by offering an updated review of studies that used TMS and a new group of studies using tES. These recent studies shed new light on our understanding of the neuropsychology of temporal processing. Nevertheless, the present review also allows critical observations regarding the specificity of each method of stimulation used deserve additional attention; as well, some limitations and criticisms of the studies that used brain stimulation techniques to understand temporal processing should be highlighted.

Focality and intensity of stimulation. TMS has better temporal and spatial resolutions than tES has. In fact, tES has usually been applied through two large electrodes, with both of them on the scalp or with one of them placed at an extra-cephalic location (neck or shoulder). Models are being developed that might give some insight into the distribution of the current flow and allow better predictions about the likely sites stimulated. Moreover, smaller electrodes $(4 \times 1$ high definition tES) have been developed and used with success in other domains [72, 140, 143]. Although TMS can induce distal effects due to brain connectivity [144], a standard figure-eight coil allows a more focal direct stimulation compared to tES. Moreover, TMS may induce immediate behavioural effect attesting that the stimulation reached the neural tissue; indeed a single TMS pulse to the motor cortex causes muscle twitches on the opposite side of the body. However, tES produces no similar 
effects on behaviour so that there is no immediate indication of the success of the stimulation.

Although the effect of tES stimulation can be quantified using other neurophysiological techniques [85], at the present time, the intensity is simply quantified in terms of the current flow between the two electrodes.

Safety and sensation reported. Both TMS and tES are generally safe if used properly. However, seizures are a well-recognised potential serious adverse effect of repetitive TMS. Stronger sensations are normally reported during and after TMS. In particular, scalp sensation and pain are the most common side effects of TMS which can reduce tolerability [145]. Moreover, TMS produces a loud click, a broadband acoustic artefact, potentially greater as loud $120 \mathrm{~dB}$ of sound pressure level, which originates from the rapid stimulation coil deformation. The intensity of sound emanating, for example, from rTMS can potentially cause acoustic trauma [146]. Without hearing protection, the Occupational Safety and Health Administration (OSHA) restricts the exposure to such impulsive noises if they are louder than $>140 \mathrm{~dB}$ of sound pressure level [147]. The sound and the sensation produced by TMS not only create discomfort for the participants but also have some theoretical consequences in the study of time processing. In fact, a number of studies have previously reported that the presentation of a rapid series of auditory clicks alone is capable of leading to the subjective lengthening of perceived duration, possibly by increasing arousal, thereby increasing the speed of the pacemaker [65, 67, 148]. Despite the temporal and spatial limitation of tES, less sensation and no sound is reported during stimulation. Most often reported tES effects are tingling and itching sensations under the electrodes, headache, and tiredness $[68,85]$. In particular, less sensory sensations are reported during tRNS, compared to tDCS [84]. Therefore, the application of tRNS might be better suited for placebo-controlled studies [85].

Reproducibility in brain stimulation research. Probably the most critical issue when it comes to analysing the effects of brain stimulation is the variety of results observed with the different stimulation techniques. Even if some general conclusions can be drawn when different 
studies involving the use of non-invasive brain stimulation techniques to study time processing are compared, clear conclusions are prevented by many methodological differences.

This work was originally motivated by a desire to conduct a meta-analysis, but it soon became evident that it would be impossible to pursue this idea; it was not possible to group the studies considering the variety of areas, tasks and dependent variables considered. The great methodological variability between studies can explain the different results observed and the difficulty in replicating previous findings. An additional limitation is related to the sample size, which is very small in most TMS and tES studies $[19,149]$. The number of participants is on average 12.13 ( $S D=4.98$; range 5-24) for TMS studies and $12.42(S D=2.51$; range 9-16) for tES studies. In addition, the assessment of the real effect of TMS and tES is further complicated by a potential publication bias leading to over-reporting significant findings. It is possible to overcome this limitation by entering the publication bias into meta-analyses or by adopting the pre-registered avenue for TMS and tES studies; in the latter case, this would make reporting their outcome possible independently of whether the results are significant or not [149]. This procedure can result in more accurate estimates of the efficacy of stimulating techniques. Moreover, allowing open access to raw data would offer researchers the opportunity to pool more easily raw data from experiments with small samples, but similar experimental designs. 


\section{Acknowledgements}

The information in this manuscript and the manuscript itself has never been published either electronically or in print. There are no financial or other relationships that could be interpreted as a conflict of interest affecting this manuscript. This research received no specific grant from any funding agency from either the commercial or the not-for-profit sectors. The authors gratefully thank Prof. Patrizio Tressoldi and Mariagrazia Capizzi for their comments and help in editing the final version. 


\section{References}

1. Grondin, S., Psychology of time. 2008: Emerald Group Publishing.

2. Gibbon, J., R.M. Church, and W.H. Meck, Scalar timing in memory. Annals of the new York Academy of Sciences, 1984. 423(1): p. 52-77.

3. Treisman, M., Temporal discrimination and the indifference interval: Implications for a model of the" internal clock". Psychological Monographs: General and Applied, 1963. 77(13): p. 1.

4. Kononowicz, T.W., H. Van Rijn, and W.H. Meck, Timing and time perception: A critical review of neural timing signatures before, during, and after the to-be-timed interval.

Stevens' Handbook of Experimental Psychology and Cognitive Neuroscience, 2018. 1: p. 138.

5. Meck, W.H., Neuroanatomical localization of an internal clock: a functional link between mesolimbic, nigrostriatal, and mesocortical dopaminergic systems. Brain research, 2006. 1109(1): p. 93-107.

6. Merchant, H., D.L. Harrington, and W.H. Meck, Neural basis of the perception and estimation of time. Annual review of neuroscience, 2013. 36: p. 313-336.

7. Muller, T. and A.C. Nobre, Perceiving the passage of time: neural possibilities. Annals of the new York Academy of Sciences, 2014. 1326(1): p. 60-71.

8. Paton, J.J. and D.V. Buonomano, The neural basis of timing: distributed mechanisms for diverse functions. Neuron, 2018. 98(4): p. 687-705.

9. Wiener, M., P. Turkeltaub, and H.B. Coslett, The image of time: a voxel-wise meta-analysis. Neuroimage, 2010. 49(2): p. 1728-1740.

10. Nani, A., et al., The Neural Correlates of Time: A Meta-analysis of Neuroimaging Studies. Journal of cognitive neuroscience, 2019: p. 1-31.

11. Coull, J.T., R.-K. Cheng, and W.H. Meck, Neuroanatomical and neurochemical substrates of timing. Neuropsychopharmacology, 2011. 36(1): p. 3.

12. Rammsayer, T.H., Neuropharmacological approaches to human timing. Psychology of time, 2008: p. 295-320.

13. Jones, C.R. and M. Jahanshahi, Motor and perceptual timing in Parkinson's disease, in Neurobiology of Interval Timing. 2014, Springer. p. 265-290.

14. Piras, F., et al., Time dysperception perspective for acquired brain injury. Frontiers in neurology, 2014. 4: p. 217.

15. Rubia, K. and A. Smith, The neural correlates of cognitive time management: a review. Acta neurobiologiae experimentalis, 2004.

16. Bueti, D. and V. Walsh, The parietal cortex and the representation of time, space, number and other magnitudes. Philosophical Transactions of the Royal Society B: Biological Sciences, 2009. 364(1525): p. 1831-1840.

17. Buonomano, D.V. and W. Maass, State-dependent computations: spatiotemporal processing in cortical networks. Nature Reviews Neuroscience, 2009. 10(2): p. 113.

18. Santarnecchi, E., et al., Enhancing cognition using transcranial electrical stimulation. Current Opinion in Behavioral Sciences, 2015. 4: p. 171-178.

19. Héroux, M.E., et al., Questionable science and reproducibility in electrical brain stimulation research. PLoS One, 2017. 12(4): p. e0175635.

20. Block, R.A., S. Grondin, and D. Zakay, Prospective and retrospective timing processes: Theories, methods, and findings, in Timing and Time Perception: Procedures, Measures, \& Applications. 2018, Brill. p. 32-51. 
21. Grondin, S., Timing and time perception: a review of recent behavioral and neuroscience findings and theoretical directions. Attention, Perception, \& Psychophysics, 2010. 72(3): p. 561-582.

22. Capizzi, M. and Á. Correa, Measuring Temporal Preparation, in Timing and Time Perception: Procedures, Measures, \& Applications. 2018, BRILL. p. 216-232.

23. Coull, J. and A. Nobre, Dissociating explicit timing from temporal expectation with fMRI. Current opinion in neurobiology, 2008. 18(2): p. 137-144.

24. Vallesi, A., T. Shallice, and V. Walsh, Role of the prefrontal cortex in the foreperiod effect: TMS evidence for dual mechanisms in temporal preparation. Cerebral Cortex, 2006. 17(2): p. 466-474.

25. Vatakis, A., et al., Timing and Time Perception: Procedures, Measures, \&amp; Applications.

26. Zakay, D., The evasive art of subjective time measurement: Some methodological dilemmas. 1990.

27. Mioni, G., Methodological issues in the study of prospective timing, in Timing and time perception: procedures, measures, \& applications. 2018, BRILL. p. 79-97.

28. Bausenhart, K.M., Assessing duration discrimination: Psychophysical methods and psychometric function analysis, in Timing and Time Perception: Procedures, Measures, \& Applications. 2018, BRILL. p. 52-78.

29. Penney, T.B. and X. Cheng, Duration Bisection: A User's Guide, in Timing and Time Perception: Procedures, Measures, \& Applications. 2018, BRILL. p. 98-127.

30. Grondin, S., Violation of the scalar property for time perception between 1 and 2 seconds: evidence from interval discrimination, reproduction, and categorization. Journal of Experimental Psychology: Human Perception and Performance, 2012. 38(4): p. 880.

31. Grondin, S., About the (non) scalar property for time perception, in Neurobiology of interval timing. 2014, Springer. p. 17-32.

32. Koelewijn, T., A. Bronkhorst, and J. Theeuwes, Attention and the multiple stages of multisensory integration: A review of audiovisual studies. Acta psychologica, 2010. 134(3): p. 372-384.

33. Grondin, S., Sensory modalities and temporal processing. 2003.

34. Grondin, S. and J.D. McAuley, Duration discrimination in crossmodal sequences. Perception, 2009. 38(10): p. 1542-1559.

35. Gontier, E., et al., EEG investigations of duration discrimination: the intermodal effect is induced by an attentional bias. PLoS One, 2013. 8(8): p. e74073.

36. Allman, M.J., B. Yin, and W.H. Meck, Time in the psychopathological mind. Subjective time: The philosophy, psychology, and neuroscience of temporality, 2014: p. 637-654.

37. Mioni, G., S. Grondin, and F. Stablum, Temporal dysfunction in traumatic brain injury patients: primary or secondary impairment? Frontiers in human neuroscience, 2014. 8: p. 269.

38. Lewis, P.A. and R.C. Miall, Distinct systems for automatic and cognitively controlled time measurement: evidence from neuroimaging. Current opinion in neurobiology, 2003. 13(2): p. $250-255$.

39. Grondin, S., G. Meilleur-Wells, and R. Lachance, When to start explicit counting in a timeintervals discrimination task: A critical point in the timing process of humans. Journal of Experimental Psychology: Human Perception and Performance, 1999. 25(4): p. 993.

40. Grondin, S., B. Ouellet, and M.-E. Roussel, Benefits and limits of explicit counting for discriminating temporal intervals. Canadian Journal of Experimental Psychology/Revue canadienne de psychologie expérimentale, 2004. 58(1): p. 1. 
41. Grondin, S. and P.R. Killeen, Tracking time with song and count: Different Weber functions for musicians and nonmusicians. Attention, Perception, \& Psychophysics, 2009. 71(7): p. 1649-1654.

42. Buhusi, C.V. and W.H. Meck, What makes us tick? Functional and neural mechanisms of interval timing. Nature Reviews Neuroscience, 2005. 6(10): p. 755.

43. Rammsayer, T.H., Neuropharmacological evidence for different timing mechanisms in humans. The Quarterly Journal of Experimental Psychology: Section B, 1999. 52(3): p. 273286.

44. Jahanshahi, M. and J. Rothwell, Transcranial magnetic stimulation studies of cognition: an emerging field. Experimental Brain Research, 2000. 131(1): p. 1-9.

45. Walsh, V. and A. Cowey, Transcranial magnetic stimulation and cognitive neuroscience. Nature Reviews Neuroscience, 2000. 1(1): p. 73.

46. Paulus, W., Transcranial electrical stimulation (tES-tDCS; tRNS, tACS) methods. Neuropsychological rehabilitation, 2011. 21(5): p. 602-617.

47. Priori, A., M. Hallett, and J.C. Rothwell, Repetitive transcranial magnetic stimulation or transcranial direct current stimulation? Brain stimulation, 2009. 2(4): p. 241-245.

48. Barker, A.T., R. Jalinous, and I.L. Freeston, Non-invasive magnetic stimulation of human motor cortex. The Lancet, 1985. 325(8437): p. 1106-1107.

49. Miniussi, C., M. Ruzzoli, and V. Walsh, The mechanism of transcranial magnetic stimulation in cognition. cortex, 2010. 46(1): p. 128-130.

50. Rossi, S., et al., Safety, ethical considerations, and application guidelines for the use of transcranial magnetic stimulation in clinical practice and research. Clinical Neurophysiology, 2009. 120(12): p. 2008-2039.

51. Hallett, M., Transcranial magnetic stimulation: a primer. Neuron, 2007. 55(2): p. 187-199.

52. Caparelli, E., et al., Is $1 \mathrm{~Hz}$ rTMS always inhibitory in healthy individuals? The open neuroimaging journal, 2012. 6: p. 69.

53. Suppa, A., et al., Ten years of theta burst stimulation in humans: established knowledge, unknowns and prospects. Brain stimulation, 2016. 9(3): p. 323-335.

54. Chung, S.W., et al., Use of theta-burst stimulation in changing excitability of motor cortex: a systematic review and meta-analysis. Neuroscience \& Biobehavioral Reviews, 2016. 63: p. 43-64.

55. Huang, Y.-Z., et al., Theta burst stimulation of the human motor cortex. Neuron, 2005. 45(2): p. 201-206.

56. Hamada, F.N., et al., An internal thermal sensor controlling temperature preference in Drosophila. Nature, 2008. 454(7201): p. 217.

57. Stefan, K., et al., Induction of plasticity in the human motor cortex by paired associative stimulation. Brain, 2000. 123(3): p. 572-584.

58. Casula, E.P., et al., Spike-timing-dependent plasticity in the human dorso-lateral prefrontal cortex. Neuroimage, 2016. 143: p. 204-213.

59. Thielscher, A. and T. Kammer, Electric field properties of two commercial figure-8 coils in TMS: calculation of focality and efficiency. Clinical Neurophysiology, 2004. 115(7): p. 1697-1708.

60. Schmidt, S., et al., Nonphysiological factors in navigated TMS studies; confounding covariates and valid intracortical estimates. Human brain mapping, 2015. 36(1): p. 40-49.

61. Romero, M.C., et al., Neural effects of transcranial magnetic stimulation at the single-cell level. Nature Communications, 2019. 10(1): p. 2642.

62. Ilmoniemi, R.J., et al., Neuronal responses to magnetic stimulation reveal cortical reactivity and connectivity. Neuroreport, 1997. 8(16): p. 3537-3540. 
63. Casula, E.P., et al., Cerebellar theta burst stimulation modulates the neural activity of interconnected parietal and motor areas. Scientific reports, 2016. 6: p. 36191.

64. Casula, E., et al., Effects of pulse width, waveform and current direction in the cortex: A combined cTMS-EEG study. Brain stimulation, 2018. 11(5): p. 1063-1070.

65. Moss, J.H. and J.K. Maner, The Clock Is Ticking. Human Nature, 2014. 25(3): p. 328-341.

66. Penton-Voak, I.S., et al., Speeding up an internal clock in humans? Effects of click trains on subjective duration. Journal of Experimental Psychology: Animal Behavior Processes, 1996. 22(3): p. 307.

67. Wearden, J., E.A. Williams, and L.A. Jones, What speeds up the internal clock? Effects of clicks and flicker on duration judgements and reaction time. The Quarterly Journal of Experimental Psychology, 2017. 70(3): p. 488-503.

68. Antal, A., et al., Low intensity transcranial electric stimulation: safety, ethical, legal regulatory and application guidelines. Clinical Neurophysiology, 2017. 128(9): p. 17741809.

69. Woods, A.J., et al., A technical guide to tDCS, and related non-invasive brain stimulation tools. Clinical Neurophysiology, 2016. 127(2): p. 1031-1048.

70. Antal, A., et al., Excitability changes induced in the human primary visual cortex by transcranial direct current stimulation: direct electrophysiological evidence. Investigative ophthalmology \& visual science, 2004. 45(2): p. 702-707.

71. Stagg, C.J., et al., Neurochemical effects of theta burst stimulation as assessed by magnetic resonance spectroscopy. Journal of Neurophysiology, 2009. 101(6): p. 2872-2877.

72. Costa, T.L., et al., Transcranial direct current stimulation as a tool in the study of sensoryperceptual processing. Attention, Perception, \& Psychophysics, 2015. 77(6): p. 1813-1840.

73. Jacobson, L., M. Koslowsky, and M. Lavidor, tDCS polarity effects in motor and cognitive domains: a meta-analytical review. Experimental Brain Research, 2012. 216(1): p. 1-10.

74. Herrmann, C.S., et al., Transcranial alternating current stimulation: a review of the underlying mechanisms and modulation of cognitive processes. Frontiers in human neuroscience, 2013. 7: p. 279.

75. Miniussi, C., J.A. Harris, and M. Ruzzoli, Modelling non-invasive brain stimulation in cognitive neuroscience. Neuroscience \& Biobehavioral Reviews, 2013. 37(8): p. 1702-1712.

76. Paulus, W., M.A. Nitsche, and A. Antal, Application of transcranial electric stimulation (tDCS, tACS, tRNS): From motor-evoked potentials towards modulation of behaviour. European Psychologist, 2016. 21(1): p. 4.

77. Schwarzkopf, D.S., J. Silvanto, and G. Rees, Stochastic resonance effects reveal the neural mechanisms of transcranial magnetic stimulation. Journal of Neuroscience, 2011. 31(9): p. 3143-3147.

78. Stacey, W.C. and D.M. Durand, Stochastic resonance improves signal detection in hippocampal CA1 neurons. Journal of Neurophysiology, 2000. 83(3): p. 1394-1402.

79. Inukai, Y., et al., Comparison of three non-invasive transcranial electrical stimulation methods for increasing cortical excitability. Frontiers in human neuroscience, 2016. 10: p. 668.

80. Moliadze, V., G. Fritzsche, and A. Antal, Comparing the efficacy of excitatory transcranial stimulation methods measuring motor evoked potentials. Neural plasticity, 2014. 2014.

81. Terney, D., et al., Increasing human brain excitability by transcranial high-frequency random noise stimulation. Journal of Neuroscience, 2008. 28(52): p. 14147-14155.

82. Antal, A. and C.S. Herrmann, Transcranial alternating current and random noise stimulation: possible mechanisms. Neural plasticity, 2016. 2016.

83. Moreno-Duarte, I., et al., Transcranial electrical stimulation: transcranial direct current stimulation (tDCS), transcranial alternating current stimulation (tACS), transcranial pulsed 
current stimulation (tPCS), and transcranial random noise stimulation (tRNS), in The stimulated brain. 2014, Elsevier. p. 35-59.

84. Ambrus, G.G., W. Paulus, and A. Antal, Cutaneous perception thresholds of electrical stimulation methods: comparison of tDCS and tRNS. Clinical Neurophysiology, 2010. 121(11): p. 1908-1914.

85. Fertonani, A., C. Ferrari, and C. Miniussi, What do you feel if I apply transcranial electric stimulation? Safety, sensations and secondary induced effects. Clinical Neurophysiology, 2015. 126(11): p. 2181-2188.

86. Liberati, A., et al., The PRISMA statement for reporting systematic reviews and metaanalyses of studies that evaluate health care interventions: explanation and elaboration. PLoS medicine, 2009. 6(7): p. e1000100.

87. Riemer, M., et al., Space, time, and numbers in the right posterior parietal cortex: Differences between response code associations and congruency effects. Neuroimage, 2016. 129: p. 72-79.

88. Ivry, R.B., S. Keele, and H. Diener, Dissociation of the lateral and medial cerebellum in movement timing and movement execution. Experimental Brain Research, 1988. 73(1): p. 167-180.

89. Nichelli, P., D. Alway, and J. Grafman, Perceptual timing in cerebellar degeneration. Neuropsychologia, 1996. 34(9): p. 863-871.

90. Mangels, J.A., R.B. Ivry, and N. Shimizu, Dissociable contributions of the prefrontal and neocerebellar cortex to time perception. Cognitive Brain Research, 1998. 7(1): p. 15-39.

91. Spencer, R.M. and R.B. Ivry, Comparison of patients with Parkinson's disease or cerebellar lesions in the production of periodic movements involving event-based or emergent timing. Brain and cognition, 2005. 58(1): p. 84-93.

92. Breska, A. and R.B. Ivry, Double dissociation of single-interval and rhythmic temporal prediction in cerebellar degeneration and Parkinson's disease. Proceedings of the National Academy of Sciences, 2018. 115(48): p. 12283-12288.

93. Koch, G., et al., Repetitive TMS of cerebellum interferes with millisecond time processing. Experimental Brain Research, 2007. 179(2): p. 291-299.

94. Lee, K.-H., et al., The role of the cerebellum in subsecond time perception: evidence from repetitive transcranial magnetic stimulation. Journal of cognitive neuroscience, 2007. 19(1): p. $147-157$.

95. Grube, M., et al., Transcranial magnetic theta-burst stimulation of the human cerebellum distinguishes absolute, duration-based from relative, beat-based perception of subsecond time intervals. Frontiers in psychology, 2010. 1: p. 171.

96. Fierro, B., et al., Role of the cerebellum in time perception: a TMS study in normal subjects. Journal of the neurological sciences, 2007. 263(1-2): p. 107-112.

97. Gironell, A., et al., Lack of prefrontal repetitive transcranial magnetic stimulation effects in time production processing. European journal of neurology, 2005. 12(11): p. 891-896.

98. Koch, G., M. Oliveri, and C. Caltagirone, Neural networks engaged in milliseconds and seconds time processing: evidence from transcranial magnetic stimulation and patients with cortical or subcortical dysfunction. Philosophical Transactions of the Royal Society B: Biological Sciences, 2009. 364(1525): p. 1907-1918.

99. Wiener, M., Transcranial magnetic stimulation studies of human time perception: a primer. Timing \& Time Perception, 2014. 2(3): p. 233-260.

100. Gooch, C.M., et al., Interval timing disruptions in subjects with cerebellar lesions. Neuropsychologia, 2010. 48(4): p. 1022-1031.

101. Harrington, D.L., et al., Does the representation of time depend on the cerebellum? Effect of cerebellar stroke. Brain, 2004. 127(3): p. 561-574. 
102. Teki, S., M. Grube, and T.D. Griffiths, A unified model of time perception accounts for duration-based and beat-based timing mechanisms. Frontiers in integrative neuroscience, 2012. 5: p. 90.

103. Bueti, D., B. Bahrami, and V. Walsh, Sensory and association cortex in time perception. Journal of cognitive neuroscience, 2008. 20(6): p. 1054-1062.

104. Kanai, R., et al., Modality-independent role of the primary auditory cortex in time estimation. Experimental Brain Research, 2011. 209(3): p. 465-471.

105. Salvioni, P., et al., How the visual brain encodes and keeps track of time. Journal of Neuroscience, 2013. 33(30): p. 12423-12429.

106. Mioni, G., et al., The role of primary auditory and visual cortices in temporal processing: A tDCS approach. Behavioural brain research, 2016. 313: p. 151-157.

107. Mioni, G., Modulating Subjective Time Perception with Transcranial Random Noise Stimulation (tRNS). Journal of Cognitive Enhancement, 2019: p. 1-11.

108. Shuler, M.G. and M.F. Bear, Reward timing in the primary visual cortex. Science, 2006. 311(5767): p. 1606-1609.

109. Coull, J.T., B. Nazarian, and F. Vidal, Timing, storage, and comparison of stimulus duration engage discrete anatomical components of a perceptual timing network. Journal of cognitive neuroscience, 2008. 20(12): p. 2185-2197.

110. Giovannelli, F., et al., “... the times they aren't a-changin'...” rTMS does not affect basic mechanisms of temporal discrimination: A pilot study with ERPs. Neuroscience, 2014. 278: p. 302-312.

111. Bueti, D., E.V. van Dongen, and V. Walsh, The role of superior temporal cortex in auditory timing. PLoS One, 2008. 3(6): p. e2481.

112. Bolognini, N., et al., Tactile temporal processing in the auditory cortex. Journal of cognitive neuroscience, 2010. 22(6): p. 1201-1211.

113. Franssen, V., A. Vandierendonck, and A. Van Hiel, Duration estimation and the phonological loop: Articulatory suppression and irrelevant sounds. Psychological research, 2006. 70(4): p. 304-316.

114. Hickok, G., et al., Auditory-motor interaction revealed by fMRI: speech, music, and working memory in area Spt. Journal of cognitive neuroscience, 2003. 15(5): p. 673-682.

115. Koch, G., et al., Underestimation of time perception after repetitive transcranial magnetic stimulation. Neurology, 2003. 60(11): p. 1844-1846.

116. Jones, C.R., et al., The right dorsolateral prefrontal cortex is essential in time reproduction: an investigation with repetitive transcranial magnetic stimulation. Experimental Brain Research, 2004. 158(3): p. 366-372.

117. Cohen Kadosh, R., N. Bien, and A.T. Sack, Automatic and intentional number processing both rely on intact right parietal cortex: a combined FMRI and neuronavigated TMS study. Frontiers in human neuroscience, 2012. 6: p. 2.

118. Mioni, G., et al., A tRNS investigation of the sensory representation of time. Scientific reports, 2018. 8.

119. Santi, A., et al., The perception of empty and filled time intervals by rats. Behavioural processes, 2005. 70(3): p. 247-263.

120. Zakay, D. and R.A. Block, The role of attention in time estimation processes, in Advances in psychology. 1996, Elsevier. p. 143-164.

121. Dusek, P., et al., Theta-burst transcranial magnetic stimulation over the supplementary motor area decreases variability of temporal estimates. Neuro endocrinology letters, 2011. 32(4): p. 481.

122. Schwartze, M., K. Rothermich, and S.A. Kotz, Functional dissociation of pre-SMA and SMA-proper in temporal processing. Neuroimage, 2012. 60(1): p. 290-298. 
123. Protopapa, F., et al., Chronotopic maps in human supplementary motor area. PLoS biology, 2019. 17(3): p. e3000026.

124. Rao, S.M., A.R. Mayer, and D.L. Harrington, The evolution of brain activation during temporal processing. Nature neuroscience, 2001. 4(3): p. 317.

125. Bueti, D., et al., Encoding of temporal probabilities in the human brain. Journal of Neuroscience, 2010. 30(12): p. 4343-4352.

126. Pouthas, V., et al., Neural network involved in time perception: an fMRI study comparing long and short interval estimation. Human brain mapping, 2005. 25(4): p. 433-441.

127. McDonald, J.J., W.A. Teder-Sälejärvi, and L.M. Ward, Multisensory integration and crossmodal attention effects in the human brain. Science, 2001. 292(5523): p. 1791-1791.

128. Rohe, T. and U. Noppeney, Distinct computational principles govern multisensory integration in primary sensory and association cortices. Current Biology, 2016. 26(4): p. 509-514.

129. Alexander, I., A. Cowey, and V. Walsh, The right parietal cortex and time perception: back to Critchley and the Zeitraffer phenomenon. Cognitive Neuropsychology, 2005. 22(3-4): p. 306-315.

130. Riemer, M., D. Rhodes, and T. Wolbers, Systematic underreproduction of time is independent of judgment certainty. Neural plasticity, 2016. 2016.

131. Dormal, V., M. Andres, and M. Pesenti, Dissociation of numerosity and duration processing in the left intraparietal sulcus: a transcranial magnetic stimulation study. cortex, 2008. 44(4): p. 462-469.

132. Wiener, M., et al., Fast forward: supramarginal gyrus stimulation alters time measurement. Journal of cognitive neuroscience, 2010. 22(1): p. 23-31.

133. Wiener, M., et al., Parietal influence on temporal encoding indexed by simultaneous transcranial magnetic stimulation and electroencephalography. Journal of Neuroscience, 2012. 32(35): p. 12258-12267.

134. Oliveri, M., et al., Representation of time intervals in the right posterior parietal cortex: implications for a mental time line. Neuroimage, 2009. 46(4): p. 1173-1179.

135. Rocha, K., et al., Low-frequency rTMS stimulation over superior parietal cortex medially improves time reproduction and increases the right dorsolateral prefrontal cortex predominance. International Journal of Neuroscience, 2019. 129(6): p. 523-533.

136. Vicario, C., D. Martino, and G. Koch, Temporal accuracy and variability in the left and right posterior parietal cortex. Neuroscience, 2013. 245: p. 121-128.

137. Javadi, A.H., et al., Transcranial electrical brain stimulation modulates neuronal tuning curves in perception of numerosity and duration. Neuroimage, 2014. 102: p. 451-457.

138. Oyama, F., K. Ishibashi, and K. Iwanaga, Cathodal transcranial direct-current stimulation over right posterior parietal cortex enhances human temporal discrimination ability. Journal of physiological anthropology, 2017. 36(1): p. 41.

139. Bergmann, T.O., et al., Combining non-invasive transcranial brain stimulation with neuroimaging and electrophysiology: current approaches and future perspectives. Neuroimage, 2016. 140: p. 4-19.

140. Costa, T.L., et al., Contrasting effects of transcranial direct current stimulation on central and peripheral visual fields. Experimental Brain Research, 2015. 233(5): p. 1391-1397.

141. Farrer, C., et al., The angular gyrus computes action awareness representations. Cerebral Cortex, 2008. 18(2): p. 254-261.

142. Göbel, S., V. Walsh, and M.F. Rushworth, The mental number line and the human angular gyrus. Neuroimage, 2001. 14(6): p. 1278-1289. 
143. Nikolin, S., et al., Effects of High-Definition Transcranial Direct Current Stimulation (HD$t D C S)$ of the Intraparietal Sulcus and Dorsolateral Prefrontal Cortex on Working Memory and Divided Attention. Frontiers in integrative neuroscience, 2018. 12: p. 64.

144. Taylor, P.C., V. Walsh, and M. Eimer, Combining TMS and EEG to study cognitive function and cortico-cortico interactions. Behavioural brain research, 2008. 191(2): p. 141-147.

145. Peterchev, A.V., et al., Pulse width affects scalp sensation of transcranial magnetic stimulation. Brain stimulation, 2017. 10(1): p. 99-105.

146. Dhamne, S.C., et al., A measure of acoustic noise generated from transcranial magnetic stimulation coils. Brain stimulation, 2014. 7(3): p. 432-434.

147. Tringali, S., et al., Repetitive transcranial magnetic stimulation: hearing safety considerations. Brain stimulation, 2012. 5(3): p. 354-363.

148. Zaehle, T., et al., Excitability changes induced in the human auditory cortex by transcranial direct current stimulation: direct electrophysiological evidence. Experimental Brain Research, 2011. 215(2): p. 135.

149. Minarik, T., et al., The importance of sample size for reproducibility of tDCS effects. Frontiers in human neuroscience, 2016. 10: p. 453. 


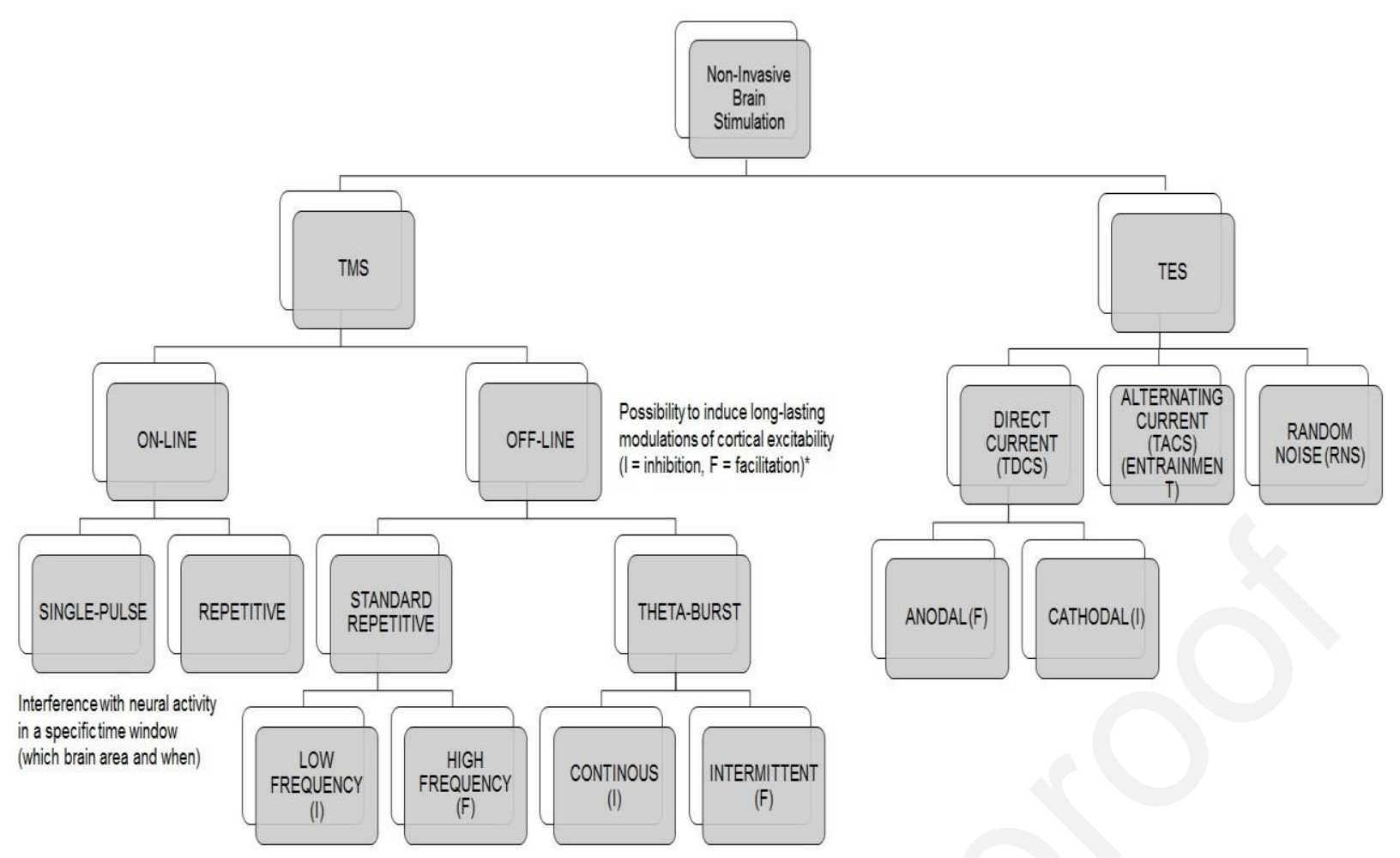

Figure 1. Graphical representation of non-invasive brain stimulation techniques and possible effects. *At least for the stimulation of the motor cortex. For stimulation of areas outside the motor system, there is no ubiquitous correspondence at the level of task performance. 
Table 1. Studies that stimulated Cerebellum; Authors in alphabetic order

\begin{tabular}{|c|c|c|c|c|c|c|c|c|c|c|c|c|}
\hline $\begin{array}{l}\text { Auth } \\
\text { or }\end{array}$ & $\begin{array}{l}\text { Ex } \\
\text { p. }\end{array}$ & $\begin{array}{l}\text { Particip } \\
\text { ants* }\end{array}$ & $\begin{array}{l}\text { Ag } \\
\text { e } \\
\text { Me } \\
\text { an } \\
\text { (SD } \\
\text { ) } \\
\end{array}$ & $\begin{array}{l}\text { TM } \\
\mathbf{S} \\
\text { fre } \\
\text { q. } \\
(\mathbf{H z} \\
) \\
\end{array}$ & $\begin{array}{l}\text { Proced } \\
\text { ure }\end{array}$ & $\begin{array}{l}\text { Cont } \\
\text { rol }\end{array}$ & Side & $\begin{array}{l}\text { Tempor } \\
\text { al tasks }\end{array}$ & $\begin{array}{l}\text { Tempo } \\
\text { ral } \\
\text { interva } \\
\text { ls }\end{array}$ & $\begin{array}{l}\text { Moda } \\
\text { lity }\end{array}$ & $\begin{array}{l}\text { Depend } \\
\text { ent } \\
\text { variabl } \\
\text { e }\end{array}$ & $\begin{array}{l}\text { Conclus } \\
\text { ions }\end{array}$ \\
\hline $\begin{array}{l}\text { Fierr } \\
\text { o et } \\
\text { al. } \\
(2007 \\
)\end{array}$ & 1 & $\begin{array}{l}10 \\
4)\end{array}(\mathrm{F}=$ & $\begin{array}{l}23 \\
(4.7 \\
)\end{array}$ & 1 & offline & $\begin{array}{l}\text { basel } \\
\text { ine }\end{array}$ & $\begin{array}{l}\text { right/ } \\
\text { left }\end{array}$ & $\begin{array}{l}\text { Time } \\
\text { discrimin } \\
\text { ation }\end{array}$ & $\begin{array}{l}\text { standar } \\
\mathrm{d}=400 \\
\mathrm{~ms} ; \\
\text { compar } \\
\text { ison } \\
300- \\
500 \mathrm{~ms}\end{array}$ & $\begin{array}{l}\text { Tactil } \\
\mathrm{e}\end{array}$ & $\begin{array}{l}\text { Percent } \\
\text { age of } \\
\text { errors }\end{array}$ & $\begin{array}{l}\text { Increase } \\
\text { d errors; } \\
\text { right } \\
\text { stimulati } \\
\text { on }\end{array}$ \\
\hline $\begin{array}{l}\text { Giro } \\
\text { nell } \\
\text { et al. } \\
(2005 \\
) \\
\end{array}$ & 1 & $16(-)$ & $\begin{array}{l}26 . \\
63 \\
(4.5 \\
7)\end{array}$ & 5 & online & $\begin{array}{l}\text { basel } \\
\text { ine }\end{array}$ & right & $\begin{array}{l}\text { Time } \\
\text { productio } \\
\mathrm{n}\end{array}$ & $180 \mathrm{~s}$ & - & $\begin{array}{l}\text { Absolut } \\
\text { e } \\
\text { relative } \\
\text { errors }\end{array}$ & $\begin{array}{l}\text { No } \\
\text { effect }\end{array}$ \\
\hline $\begin{array}{l}\text { Grub } \\
\text { e et } \\
\text { al. } \\
(2010 \\
)\end{array}$ & 1 & $\begin{array}{l}12(F= \\
0)\end{array}$ & $\begin{array}{l}23 . \\
5 \\
(4.5 \\
)\end{array}$ & $\begin{array}{l}\text { The } \\
\text { ta- } \\
\text { burs } \\
\mathrm{t}\end{array}$ & $\begin{array}{l}\text { online } \\
\text { (betwe } \\
\text { en } \\
\text { subject } \\
\text { design) }\end{array}$ & sham & $\begin{array}{l}\text { medi } \\
\text { al }\end{array}$ & $\begin{array}{l}\text { Time } \\
\text { discrimin } \\
\text { ation }\end{array}$ & $\begin{array}{l}\text { Standar } \\
\text { ds } \\
\text { Short = } \\
300 \\
\text { Long = } \\
600 \mathrm{~ms}\end{array}$ & $\begin{array}{l}\text { Audit } \\
\text { ory }\end{array}$ & $\begin{array}{l}\text { Thresho } \\
\text { ld }\end{array}$ & $\begin{array}{l}\text { Increase } \\
\text { d } \\
\text { threshol } \\
\text { d }\end{array}$ \\
\hline $\begin{array}{l}\text { Kock } \\
\text { et al. } \\
(2007 \\
)\end{array}$ & 1 & $9(-)^{* *}$ & $\begin{array}{l}22- \\
35\end{array}$ & 1 & offline & $\begin{array}{l}\text { basel } \\
\text { ine }\end{array}$ & $\begin{array}{l}\text { right/ } \\
\text { left }\end{array}$ & $\begin{array}{l}\text { Time } \\
\text { reproduct } \\
\text { ion }\end{array}$ & $\begin{array}{l}\text { Short = } \\
500 \mathrm{~ms} \\
\text { (averag } \\
\text { e); } \\
\text { Long = } \\
2000 \mathrm{~ms} \\
\text { (averag } \\
\text { e) }\end{array}$ & Visual & $\begin{array}{l}\text { Reprod } \\
\text { uced } \\
\text { time - } \\
\text { CV }\end{array}$ & $\begin{array}{l}\text { Over- } \\
\text { estimati } \\
\text { on short } \\
\text { range } \\
\text { under } \\
\text { left site } \\
\text { stimulati } \\
\text { on; no } \\
\text { effect } \\
\text { on CV }\end{array}$ \\
\hline $\begin{array}{l}\text { Kock } \\
\text { et al. } \\
(2007 \\
)\end{array}$ & 2 & $8(-)^{* * *}$ & $\begin{array}{l}22- \\
35\end{array}$ & 20 & online & $\begin{array}{l}\text { basel } \\
\text { ine }\end{array}$ & $\begin{array}{l}\text { right/ } \\
\text { left }\end{array}$ & $\begin{array}{l}\text { Time } \\
\text { reproduct } \\
\text { ion }\end{array}$ & $\begin{array}{l}\text { Short = } \\
500 \mathrm{~ms} \\
\text { (averag } \\
\text { e); } \\
\text { Long = } \\
2000 \mathrm{~ms} \\
\text { (averag } \\
\text { e) }\end{array}$ & Visual & $\begin{array}{l}\text { Reprod } \\
\text { uced } \\
\text { time - } \\
\text { CV }\end{array}$ & $\begin{array}{l}\text { Over- } \\
\text { estimati } \\
\text { on short } \\
\text { tempora } \\
\text { l } \\
\text { intervals } \\
\text { both } \\
\text { sides at } \\
\text { encodin } \\
\text { g phase; } \\
\text { no } \\
\text { effect } \\
\text { on CV }\end{array}$ \\
\hline $\begin{array}{l}\text { Lee } \\
\text { et al. } \\
(2007 \\
)\end{array}$ & 1 & $\begin{array}{l}11 \\
0)\end{array}(\mathrm{F}=$ & $\begin{array}{l}30 \\
(5.1 \\
)\end{array}$ & 1 & offline & sham & $\begin{array}{l}\text { righ/l } \\
\text { eft } \\
\text { medi } \\
\text { al }\end{array}$ & $\begin{array}{l}\text { Time } \\
\text { bisection }\end{array}$ & $\begin{array}{l}400- \\
800 \mathrm{~ms}\end{array}$ & $\begin{array}{l}\text { Audit } \\
\text { ory }\end{array}$ & $\begin{array}{l}\text { BP and } \\
\text { DL }\end{array}$ & $\begin{array}{l}\text { Over- } \\
\text { estimati } \\
\text { on after } \\
\text { right } \\
\text { and } \\
\text { medial } \\
\text { stimulati } \\
\text { on } \\
\text { compare } \\
\text { d to } \\
\text { sham }\end{array}$ \\
\hline
\end{tabular}




\begin{tabular}{|c|c|c|c|c|c|c|c|c|c|c|c|c|}
\hline $\begin{array}{l}\text { Lee } \\
\text { et al. } \\
(2007 \\
)\end{array}$ & 2 & $\begin{array}{l}11(F= \\
0)\end{array}$ & $\begin{array}{l}32 \\
(5.2 \\
)\end{array}$ & 1 & offline & sham & $\begin{array}{l}\text { righ/l } \\
\text { eft } \\
\text { medi } \\
\text { al }\end{array}$ & $\begin{array}{l}\text { Time } \\
\text { bisection }\end{array}$ & $\begin{array}{l}1000- \\
2000 \\
\mathrm{~ms}\end{array}$ & $\begin{array}{l}\text { Audit } \\
\text { ory }\end{array}$ & $\begin{array}{l}\text { BP and } \\
\text { DL }\end{array}$ & $\begin{array}{l}\text { No } \\
\text { effect } \\
\text { compare } \\
\text { d to } \\
\text { sham }\end{array}$ \\
\hline $\begin{array}{l}\text { Lee } \\
\text { et al. } \\
(2007 \\
)\end{array}$ & 3 & $\begin{array}{l}18(F= \\
0)\end{array}$ & $\begin{array}{l}27 \\
(7.8 \\
)\end{array}$ & 1 & offline & sham & $\begin{array}{l}\text { medi } \\
\text { al }\end{array}$ & $\begin{array}{l}\text { Time } \\
\text { bisection }\end{array}$ & $\begin{array}{l}\text { Short = } \\
400- \\
800 \mathrm{~ms} \\
\text { and } \\
\text { Long = } \\
1000- \\
2000 \\
\mathrm{~ms}\end{array}$ & $\begin{array}{l}\text { Audit } \\
\text { ory }\end{array}$ & $\begin{array}{l}\text { BP and } \\
\text { DL }\end{array}$ & $\begin{array}{l}\text { Over- } \\
\text { estimati } \\
\text { on after } \\
\text { medial } \\
\text { stimulati } \\
\text { on } \\
\text { compare } \\
\text { d to } \\
\text { sham } \\
\text { for short } \\
\text { intervals }\end{array}$ \\
\hline
\end{tabular}

Notes: All authors used $70 \mathrm{~mm}$ figure of eight coil. * = none of the studies used subjects' MRI for site location but based the location on previous studies; $* *=$ MRI was conducted for one participant after marking cerebellar and frontal scalp sites with capsules containing soy oil. $\mathrm{CV}=$ Coefficient of variation; $\mathrm{BP}=$ Bisection Point; DL $=\mathrm{Different}$ Linen 
Table 2. Studies that stimulated areas in Occipital cortex; authors in alphabetic order

\begin{tabular}{|c|c|c|c|c|c|c|c|c|c|c|c|c|c|}
\hline $\begin{array}{l}\text { Aut } \\
\text { hor }\end{array}$ & $\begin{array}{l}\text { Ex } \\
\text { p. }\end{array}$ & $\begin{array}{l}\text { Partici } \\
\text { pants }\end{array}$ & $\begin{array}{l}\text { Ag } \\
\text { e } \\
\text { Me } \\
\text { an } \\
\text { (S } \\
\text { D) }\end{array}$ & $\begin{array}{l}\text { TMS } \\
\text { freq. } \\
(\mathbf{H z})\end{array}$ & $\begin{array}{l}\text { Proce } \\
\text { dure }\end{array}$ & $\begin{array}{l}\text { AR } \\
\text { EA }\end{array}$ & $\begin{array}{l}\text { Con } \\
\text { trol }\end{array}$ & $\begin{array}{l}\text { Si } \\
\text { de }\end{array}$ & $\begin{array}{l}\text { Tempor } \\
\text { al tasks }\end{array}$ & $\begin{array}{l}\text { Temp } \\
\text { oral } \\
\text { interv } \\
\text { als }\end{array}$ & $\begin{array}{l}\text { Modalit } \\
\mathbf{y}\end{array}$ & $\begin{array}{l}\text { Depen } \\
\text { dent } \\
\text { variab } \\
\text { les }\end{array}$ & $\begin{array}{l}\text { Conclu } \\
\text { sions }\end{array}$ \\
\hline $\begin{array}{l}\text { Buet } \\
\text { i et } \\
\text { al. } \\
(200 \\
8) \text { a }\end{array}$ & 1 & $10(-)^{*}$ & $\begin{array}{l}29 . \\
2\end{array}$ & 12 & online & $\begin{array}{l}\text { MT/ } \\
\text { V5 }\end{array}$ & $\begin{array}{l}\text { Vert } \\
\text { ex } \\
\text { noT } \\
\text { MS }\end{array}$ & $\begin{array}{l}\text { lef } \\
\mathrm{t}\end{array}$ & $\begin{array}{l}\text { Time } \\
\text { discrimi } \\
\text { nation } \\
\text { (stimula } \\
\text { tion } \\
\text { over } \\
\text { compari } \\
\text { son } \\
\text { interval) }\end{array}$ & $\begin{array}{l}\text { standa } \\
\text { rd = } \\
600 \\
\text { ms; } \\
\text { compa } \\
\text { rison = } \\
435- \\
765 \\
\text { ms }\end{array}$ & $\begin{array}{l}\text { Visual } \\
\text { moving }\end{array}$ & $\begin{array}{l}\text { BP } \\
\text { and } \\
\text { WR }\end{array}$ & $\begin{array}{l}\text { Higher } \\
\text { WR no } \\
\text { effect } \\
\text { on BP }\end{array}$ \\
\hline $\begin{array}{l}\text { Buet } \\
\text { i et } \\
\text { al. } \\
(200 \\
8) \text { a }\end{array}$ & 2 & $10(-)^{*}$ & $\begin{array}{l}28 . \\
2\end{array}$ & 12 & online & $\begin{array}{l}\text { MT/ } \\
\text { V5 }\end{array}$ & $\begin{array}{l}\text { Vert } \\
\text { ex } \\
\text { noT } \\
\text { MS }\end{array}$ & $\begin{array}{l}\text { lef } \\
\mathrm{t}\end{array}$ & $\begin{array}{l}\text { Time } \\
\text { discrimi } \\
\text { nation } \\
\text { (stimula } \\
\text { tion } \\
\text { over } \\
\text { compari } \\
\text { son } \\
\text { interval) }\end{array}$ & $\begin{array}{l}\text { standa } \\
\text { rd = } \\
600 \\
\text { ms; } \\
\text { compa } \\
\text { rison = } \\
435- \\
765 \\
\text { ms }\end{array}$ & $\begin{array}{l}\text { Visual } \\
\text { static }\end{array}$ & $\begin{array}{l}\text { BP } \\
\text { and } \\
\text { WR }\end{array}$ & $\begin{array}{l}\text { Higher } \\
\text { WR no } \\
\text { effect } \\
\text { on BP }\end{array}$ \\
\hline $\begin{array}{l}\text { Buet } \\
\text { i et } \\
\text { al. } \\
(200 \\
8) \text { a }\end{array}$ & 4 & $9(-)^{*}$ & $\begin{array}{l}29 . \\
6\end{array}$ & 12 & online & $\begin{array}{l}\text { MT/ } \\
\text { V5 }\end{array}$ & $\begin{array}{l}\text { Vert } \\
\text { ex } \\
\text { noT } \\
\text { MS }\end{array}$ & $\begin{array}{l}\text { lef } \\
t\end{array}$ & $\begin{array}{l}\text { Time } \\
\text { discrimi } \\
\text { nation } \\
\text { (stimula } \\
\text { tion } \\
\text { over } \\
\text { compari } \\
\text { son } \\
\text { interval) }\end{array}$ & 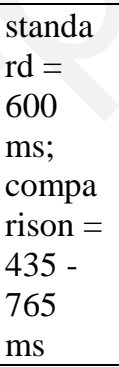 & Auditory & $\begin{array}{l}\text { BP } \\
\text { and } \\
\text { WR }\end{array}$ & $\begin{array}{l}\text { No } \\
\text { effects }\end{array}$ \\
\hline $\begin{array}{l}\text { Buet } \\
\text { i et } \\
\text { al. } \\
(200 \\
8) \text { a }\end{array}$ & 5 & $5(-)^{*}$ & 28 & 12 & online & $\begin{array}{l}\text { MT/ } \\
\text { V5 }\end{array}$ & $\begin{array}{l}\text { Vert } \\
\text { ex } \\
\text { noT } \\
\text { MS }\end{array}$ & $\begin{array}{l}\text { lef } \\
\mathrm{t}\end{array}$ & $\begin{array}{l}\text { Time } \\
\text { discrimi } \\
\text { nation } \\
\text { (stimula } \\
\text { tion } \\
\text { over } \\
\text { compari } \\
\text { son } \\
\text { interval) }\end{array}$ & $\begin{array}{l}\text { standa } \\
\text { rd = } \\
600 \\
\text { ms; } \\
\text { compa } \\
\text { rison = } \\
520- \\
680 \\
\text { ms }\end{array}$ & Auditory & $\begin{array}{l}\text { BP } \\
\text { and } \\
\text { WR }\end{array}$ & $\begin{array}{l}\text { No } \\
\text { effects }\end{array}$ \\
\hline $\begin{array}{l}\text { Kan } \\
\text { ai et } \\
\text { al. } \\
(201 \\
1)\end{array}$ & 1 & $\begin{array}{l}10(\mathrm{~F}= \\
6)^{*}\end{array}$ & $\begin{array}{l}24 . \\
3 \\
(2 . \\
8)\end{array}$ & $\begin{array}{l}\text { Theta } \\
\text { Burst }\end{array}$ & offline & V1 & $\begin{array}{l}\text { base } \\
\text { line }\end{array}$ & $\begin{array}{l}\text { lef } \\
\mathrm{t}\end{array}$ & $\begin{array}{l}\text { Time } \\
\text { discrimi } \\
\text { nation }\end{array}$ & $\begin{array}{l}\text { Standa } \\
\text { rd = } \\
600 \\
\mathrm{~ms}\end{array}$ & $\begin{array}{l}\text { Auditory } \\
\text { /visual }\end{array}$ & $\begin{array}{l}\text { Thresh } \\
\text { old }\end{array}$ & $\begin{array}{l}\text { Higher } \\
\text { thresho } \\
\text { ld in } \\
\text { visual } \\
\text { modalit } \\
\text { y }\end{array}$ \\
\hline $\begin{array}{l}\text { Salv } \\
\text { ioni } \\
\text { et al. } \\
(201 \\
3)\end{array}$ & 1 & $\begin{array}{l}14(\mathrm{~F}= \\
9)\end{array}$ & $\begin{array}{l}\mathrm{Ra} \\
\text { nge } \\
22- \\
28\end{array}$ & $\begin{array}{l}\text { Paired } \\
- \\
\text { pulses } \\
\text { (inter } \\
\text { pulse } \\
\text { interv } \\
\text { al =35 } \\
\text { ms) }\end{array}$ & online & $\begin{array}{l}\text { MT/ } \\
\text { V5 }\end{array}$ & $\begin{array}{l}\text { verte } \\
\mathrm{x}\end{array}$ & $\begin{array}{l}\text { lef } \\
t\end{array}$ & $\begin{array}{l}\text { Time } \\
\text { discrimi } \\
\text { nation } \\
\text { (stimula } \\
\text { tion } \\
\text { onset } \\
\text { standard } \\
\text { interval) }\end{array}$ & $\begin{array}{l}\text { Standa } \\
\text { rd = } \\
200 \\
\mathrm{~ms}\end{array}$ & Visual & $\begin{array}{l}\text { Thresh } \\
\text { old }\end{array}$ & $\begin{array}{l}\text { Higher } \\
\text { thresho } \\
\text { ld } \\
\text { compar } \\
\text { ed at } \\
85 \text { and } \\
120 \mathrm{~ms} \\
\text { delay }\end{array}$ \\
\hline
\end{tabular}




\begin{tabular}{|c|c|c|c|c|c|c|c|c|c|c|c|c|c|}
\hline $\begin{array}{l}\text { Salv } \\
\text { ioni } \\
\text { et al. } \\
(201 \\
3)\end{array}$ & 1 & $\begin{array}{l}14(\mathrm{~F}= \\
9)\end{array}$ & $\begin{array}{l}\mathrm{Ra} \\
\text { nge } \\
22- \\
28\end{array}$ & $\begin{array}{l}\text { Paired } \\
- \\
\text { pilses } \\
\text { (inter } \\
\text { pulse } \\
\text { interv } \\
\text { al =35 } \\
\text { ms) }\end{array}$ & online & V1 & $\begin{array}{l}\text { verte } \\
\mathrm{x}\end{array}$ & $\begin{array}{l}\text { lef } \\
\mathrm{t}\end{array}$ & $\begin{array}{l}\text { Time } \\
\text { discrimi } \\
\text { nation } \\
\text { (stimula } \\
\text { tion } \\
\text { onset } \\
\text { standard } \\
\text { interval) }\end{array}$ & $\begin{array}{l}\text { Standa } \\
\text { rd = } \\
200 \\
\mathrm{~ms}\end{array}$ & Visual & $\begin{array}{l}\text { Thresh } \\
\text { old }\end{array}$ & $\begin{array}{l}\text { Higher } \\
\text { thresho } \\
\text { ld } \\
\text { compar } \\
\text { ed at } \\
85 \text { and } \\
120 \mathrm{~ms} \\
\text { delay }\end{array}$ \\
\hline $\begin{array}{l}\text { Salv } \\
\text { ioni } \\
\text { et al. } \\
(201 \\
3)\end{array}$ & 2 & $\begin{array}{l}14(\mathrm{~F}= \\
10)\end{array}$ & $\begin{array}{l}\text { Ra } \\
\text { nge } \\
22- \\
38\end{array}$ & $\begin{array}{l}\text { Paired } \\
- \\
\text { pulses } \\
\text { (inter } \\
\text { pulse } \\
\text { interv } \\
\text { al =35 } \\
\text { ms) }\end{array}$ & online & $\begin{array}{l}\text { MT/ } \\
\text { V5 }\end{array}$ & $\begin{array}{l}\text { verte } \\
\mathrm{x}\end{array}$ & $\begin{array}{l}\text { lef } \\
t\end{array}$ & $\begin{array}{l}\text { Time } \\
\text { discrimi } \\
\text { nation } \\
\text { (stimula } \\
\text { tion } \\
\text { offset } \\
\text { standard } \\
\text { interval) }\end{array}$ & $\begin{array}{l}\text { Standa } \\
\mathrm{rd}= \\
200 \\
\mathrm{~ms}\end{array}$ & Visual & $\begin{array}{l}\text { Thresh } \\
\text { old }\end{array}$ & $\begin{array}{l}\text { Higher } \\
\text { thresho } \\
\text { ld at } 85 \\
\text { ms } \\
\text { delay }\end{array}$ \\
\hline $\begin{array}{l}\text { Salv } \\
\text { ioni } \\
\text { et al. } \\
(201 \\
3)\end{array}$ & 2 & $\begin{array}{l}14(\mathrm{~F}= \\
10)\end{array}$ & $\begin{array}{l}\text { Ra } \\
\text { nge } \\
22- \\
38\end{array}$ & $\begin{array}{l}\text { Paired } \\
- \\
\text { pulses } \\
\text { (inter } \\
\text { pulse } \\
\text { interv } \\
\text { al =35 } \\
\text { ms) }\end{array}$ & online & V1 & $\begin{array}{l}\text { verte } \\
\mathrm{x}\end{array}$ & $\begin{array}{l}\text { lef } \\
t\end{array}$ & $\begin{array}{l}\text { Time } \\
\text { discrimi } \\
\text { nation } \\
\text { (stimula } \\
\text { tion } \\
\text { offset } \\
\text { standard } \\
\text { interval) }\end{array}$ & $\begin{array}{l}\text { Standa } \\
\mathrm{rd}= \\
200 \\
\mathrm{~ms}\end{array}$ & Visual & $\begin{array}{l}\text { Thresh } \\
\text { old }\end{array}$ & $\begin{array}{l}\text { Higher } \\
\text { thresho } \\
\text { ld at } 50 \\
\text { ms } \\
\text { delay }\end{array}$ \\
\hline
\end{tabular}

Note: All authors used $70 \mathrm{~mm}$ figure of eight coil. * = study that used subjects' MRI to localize the stimulation site; MT/V5 = extrastriate visual areas; V1 = primary visual area; BP = Bisection Point; WR = Weber Ratio 
Table 3. Studies that stimulated areas of Temporal cortex; Authors in alphabetic order.

\begin{tabular}{|c|c|c|c|c|c|c|c|c|c|c|c|c|c|}
\hline $\begin{array}{l}\text { Autho } \\
\mathbf{r}\end{array}$ & p. & $\begin{array}{l}\text { Partici } \\
\text { pants }\end{array}$ & $\begin{array}{l}\text { Ag } \\
\text { e } \\
\text { Me } \\
\text { an } \\
\text { (S } \\
\text { D) }\end{array}$ & $\begin{array}{l}\text { T } \\
M \\
\text { S } \\
\text { fre } \\
\text { q. } \\
\text { (H } \\
\text { z) } \\
\end{array}$ & $\begin{array}{l}\text { Proce } \\
\text { dure }\end{array}$ & $\begin{array}{l}\text { AR } \\
\text { EA }\end{array}$ & $\begin{array}{l}\text { Cont } \\
\text { rol }\end{array}$ & $\begin{array}{l}\text { Sid } \\
\text { e }\end{array}$ & $\begin{array}{l}\text { Tempor } \\
\text { al tasks }\end{array}$ & $\begin{array}{l}\text { Tempo } \\
\text { ral } \\
\text { interv } \\
\text { als }\end{array}$ & $\begin{array}{l}\text { Moda } \\
\text { lity }\end{array}$ & $\begin{array}{l}\text { Depen } \\
\text { dent } \\
\text { variab } \\
\text { les }\end{array}$ & $\begin{array}{l}\text { Conclusi } \\
\text { ons }\end{array}$ \\
\hline $\begin{array}{l}\text { Bologn } \\
\text { ini et } \\
\text { al. } \\
(2010)\end{array}$ & 1 & $\begin{array}{l}13(F= \\
6)\end{array}$ & 35 & 1 & offline & $\begin{array}{l}\text { ST } \\
\text { G }\end{array}$ & - & left & $\begin{array}{l}\text { Time } \\
\text { discrimi } \\
\text { nation }\end{array}$ & $\begin{array}{l}\text { Standa } \\
\text { rd } 25 \\
\text { ms }\end{array}$ & $\begin{array}{l}\text { Tactil } \\
\mathrm{e}\end{array}$ & $\begin{array}{l}\text { Percen } \\
\text { tage of } \\
\text { errors, } \\
\text { sensiti } \\
\text { vity } \\
\text { (d') } \\
\text { and } \\
\text { respon } \\
\text { se } \\
\text { criterio } \\
\text { n }\end{array}$ & $\begin{array}{l}\text { Increase } \\
\mathrm{d} \\
\text { number } \\
\text { of errors } \\
\text { for ISI = } \\
180 \mathrm{~ms} \\
\text { compare } \\
\text { d to } \\
\text { other } \\
\text { conditio } \\
\text { ns }\end{array}$ \\
\hline $\begin{array}{l}\text { Bueti } \\
\text { et al. } \\
(2008) \\
\text { b }\end{array}$ & 1 & $\begin{array}{l}8(\mathrm{~F}= \\
1)^{*}\end{array}$ & $\begin{array}{l}28 . \\
2\end{array}$ & 10 & online & $\begin{array}{l}\text { ST } \\
\text { G }\end{array}$ & $\begin{array}{l}\text { verte } \\
\mathrm{x}\end{array}$ & $\begin{array}{l}\text { Ri } \\
\text { ght } \\
\text { left }\end{array}$ & $\begin{array}{l}\text { Time } \\
\text { discrimi } \\
\text { nation }\end{array}$ & $\begin{array}{l}\text { standar } \\
d= \\
600 \\
\text { ms; } \\
\text { compar } \\
\text { ison = } \\
\pm 10 \text {, } \\
\pm 20 \text {, } \\
\pm 40\end{array}$ & $\begin{array}{l}\text { Audit } \\
\text { ory }\end{array}$ & $\begin{array}{l}\text { BP and } \\
\text { JND }\end{array}$ & $\begin{array}{l}\text { Lower } \\
\text { accuracy } \\
\text { and } \\
\text { increase } \\
\text { d } \\
\text { variabilit } \\
\text { y only } \\
\text { right } \\
\text { side }\end{array}$ \\
\hline $\begin{array}{l}\text { Giovan } \\
\text { nelli et } \\
\text { al. } \\
(2014)\end{array}$ & 1 & $\begin{array}{l}10(F= \\
7)\end{array}$ & $\begin{array}{l}29 . \\
1\end{array}$ & 1 & offline & $\begin{array}{l}\text { ST } \\
\text { G }\end{array}$ & $\mathrm{Oz}$ & $\begin{array}{l}\text { rig } \\
\text { ht }\end{array}$ & $\begin{array}{l}\text { Time } \\
\text { discrimi } \\
\text { nation }\end{array}$ & $\begin{array}{l}\text { Standa } \\
\text { rd = } \\
1000 \\
\text { ms; } \\
\text { compar } \\
\text { ison = } \\
800, \\
1000, \\
1200 \\
\text { ms }\end{array}$ & $\begin{array}{l}\text { Audit } \\
\text { ory }\end{array}$ & $\begin{array}{l}\text { Percen } \\
\text { tage of } \\
\text { correct } \\
\text { respon } \\
\text { ses and } \\
\text { RT }\end{array}$ & $\begin{array}{l}\text { No } \\
\text { effect on } \\
\text { accuracy } \\
\text {; General } \\
\text { faster } \\
\text { RT after } \\
\text { stimulati } \\
\text { on }\end{array}$ \\
\hline $\begin{array}{l}\text { Kanai } \\
\text { et al. } \\
(2011)\end{array}$ & 1 & $\begin{array}{l}10(\mathrm{~F}= \\
6)^{*}\end{array}$ & $\begin{array}{l}\text { Me } \\
\text { an } \\
24 . \\
3 \\
(2 . \\
8)\end{array}$ & $\begin{array}{l}\text { Th } \\
\text { eta } \\
\text { bur } \\
\text { st }\end{array}$ & offline & A1 & $\begin{array}{l}\text { basel } \\
\text { ine }\end{array}$ & $\begin{array}{l}\text { rig } \\
\text { ht }\end{array}$ & $\begin{array}{l}\text { Time } \\
\text { discrimi } \\
\text { nation }\end{array}$ & $\begin{array}{l}\text { Standa } \\
\mathrm{rd}= \\
600 \mathrm{~ms}\end{array}$ & $\begin{array}{l}\text { Audit } \\
\text { ory } \\
\text { visual }\end{array}$ & $\begin{array}{l}\text { Thresh } \\
\text { old }\end{array}$ & $\begin{array}{l}\text { Increase } \\
\mathrm{d} \\
\text { discrimi } \\
\text { nation } \\
\text { threshold } \\
\text { independ } \\
\text { ently of } \\
\text { the } \\
\text { modality }\end{array}$ \\
\hline
\end{tabular}

Note: $*$ = study that used subjects' MRI to localize the stimulation site; SI = Primary Somatosensory cortex; STG = Superior Temporal Gyrus. BP = Bisection Point; JND = Just Noticeable Difference; RT = Reaction time. 
Table 4. Studies that stimulated areas on Frontal cortex; Authors in alphabetic order

\begin{tabular}{|c|c|c|c|c|c|c|c|c|c|c|c|c|c|}
\hline $\begin{array}{l}\text { Autho } \\
\mathbf{r}\end{array}$ & $\begin{array}{l}\mathbf{E} \\
\mathbf{x} \\
\mathbf{p}\end{array}$ & $\begin{array}{l}\text { Partici } \\
\text { pants }\end{array}$ & $\begin{array}{l}\text { Ag } \\
\text { e } \\
\text { Me } \\
\text { an } \\
\text { (S } \\
\text { D) }\end{array}$ & $\begin{array}{l}T \\
M \\
S \\
\text { fre } \\
\text { q. } \\
\text { (H } \\
\text { z) }\end{array}$ & $\begin{array}{l}\text { Proce } \\
\text { dure }\end{array}$ & $\begin{array}{l}\text { AR } \\
\text { EA }\end{array}$ & $\begin{array}{l}\text { Con } \\
\text { trol }\end{array}$ & $\begin{array}{l}\text { Si } \\
\text { de }\end{array}$ & $\begin{array}{l}\text { Tempor } \\
\text { al tasks }\end{array}$ & $\begin{array}{l}\text { Temp } \\
\text { oral } \\
\text { interv } \\
\text { als }\end{array}$ & $\begin{array}{l}\text { Mod } \\
\text { ality }\end{array}$ & $\begin{array}{l}\text { Depende } \\
\text { nt } \\
\text { variables }\end{array}$ & $\begin{array}{l}\text { Conclu } \\
\text { sions }\end{array}$ \\
\hline $\begin{array}{l}\text { Dusek } \\
\text { et al. } \\
(2011)\end{array}$ & 1 & $\begin{array}{l}19(\mathrm{~F}= \\
11)\end{array}$ & $\begin{array}{l}25 . \\
9 \\
(3)\end{array}$ & $\begin{array}{l}\text { Th } \\
\text { eta } \\
\text { bur } \\
\text { st }\end{array}$ & offline & $\begin{array}{l}\text { SM } \\
\text { A }\end{array}$ & - & - & $\begin{array}{l}\text { Time } \\
\text { reprodu } \\
\text { ction }\end{array}$ & $\begin{array}{l}5,10 \\
\text { and } \\
16.82 \\
\mathrm{~s}\end{array}$ & $\begin{array}{l}\text { visua } \\
1\end{array}$ & $\begin{array}{l}\text { Reproduc } \\
\text { ed time; } \\
\text { SD } \\
\text { (variabilit } \\
\text { y) }\end{array}$ & $\begin{array}{l}\text { No } \\
\text { effect } \\
\text { on } \\
\text { accurac } \\
y ; \\
\text { Decreas } \\
\text { ed } \\
\text { variabil } \\
\text { ity } 10 \mathrm{~s} \\
\text { interval }\end{array}$ \\
\hline $\begin{array}{l}\text { Giova } \\
\text { nnelli } \\
\text { et al. } \\
(\mathbf{2 0 1 4})\end{array}$ & 1 & $\begin{array}{l}10 \\
7)\end{array}(\mathrm{F}=$ & $\begin{array}{l}29 . \\
1(- \\
)\end{array}$ & 1 & offline & $\begin{array}{l}\text { SM } \\
\mathrm{A}\end{array}$ & $\mathrm{Oz}$ & - & $\begin{array}{l}\text { Time } \\
\text { discrimi } \\
\text { nation }\end{array}$ & $\begin{array}{l}\text { Standa } \\
\text { rd = } \\
1000 \\
\text { ms; } \\
\text { compa } \\
\text { rison = } \\
800, \\
1000, \\
1200 \\
\text { ms }\end{array}$ & $\begin{array}{l}\text { audit } \\
\text { ory }\end{array}$ & $\begin{array}{l}\text { Percentag } \\
\text { e of } \\
\text { correct } \\
\text { responses } \\
\text { and RT }\end{array}$ & $\begin{array}{l}\text { No } \\
\text { effect } \\
\text { on } \\
\text { accurac } \\
\text { y; } \\
\text { General } \\
\text { faster } \\
\text { RT } \\
\text { after } \\
\text { stimulat } \\
\text { ion }\end{array}$ \\
\hline $\begin{array}{l}\text { Giron } \\
\text { ell et } \\
\text { al. } \\
(\mathbf{2 0 0 5})\end{array}$ & 1 & $16(-)$ & $\begin{array}{l}26 . \\
63 \\
(4 . \\
57) \\
\end{array}$ & 5 & online & $\begin{array}{l}\text { DL } \\
\text { PFC }\end{array}$ & $\begin{array}{l}\text { base } \\
\text { line }\end{array}$ & $\begin{array}{l}\mathrm{Ri} \\
\text { ght } \\
\text { left }\end{array}$ & $\begin{array}{l}\text { Time } \\
\text { producti } \\
\text { on }\end{array}$ & $180 \mathrm{~s}$ & - & $\begin{array}{l}\text { Absolute/ } \\
\text { relative } \\
\text { errors }\end{array}$ & $\begin{array}{l}\text { No } \\
\text { effect }\end{array}$ \\
\hline $\begin{array}{l}\text { Jones } \\
\text { et al. } \\
(2004)\end{array}$ & 1 & $\begin{array}{l}9(\mathrm{~F}= \\
3)\end{array}$ & $\begin{array}{l}30 . \\
6 \\
(6 . \\
19)\end{array}$ & 20 & online & $\begin{array}{l}\text { DL } \\
\text { PFC }\end{array}$ & $\begin{array}{l}\text { Leg } \\
\text { mot } \\
\text { or } \\
\text { area } \\
\text { and } \\
\text { sha } \\
\mathrm{m}\end{array}$ & $\begin{array}{l}\text { rig } \\
\text { ht }\end{array}$ & $\begin{array}{l}\text { Time } \\
\text { reprodu } \\
\text { ction } \\
\text { (stimula } \\
\text { tion } \\
\text { during } \\
\text { encodin } \\
\text { g or } \\
\text { reprodu } \\
\text { ction) }\end{array}$ & $\begin{array}{l}\text { Short } \\
=500 \\
\mathrm{~ms} \\
\text { (avera } \\
\text { ge); } \\
\text { Long } \\
= \\
2000 \mathrm{~m} \\
\mathrm{~s} \\
\text { (avera } \\
\text { ge) }\end{array}$ & $\begin{array}{l}\text { visua } \\
1\end{array}$ & $\begin{array}{l}\text { Reproduc } \\
\text { ed time }\end{array}$ & $\begin{array}{l}\text { Under- } \\
\text { estimati } \\
\text { on with } \\
\text { long } \\
\text { interval } \\
\text { s } \\
\text { (reprod } \\
\text { uction } \\
\text { phase) }\end{array}$ \\
\hline $\begin{array}{l}\text { Jones } \\
\text { et al. } \\
(\mathbf{2 0 0 4})\end{array}$ & 1 & $\begin{array}{l}9(\mathrm{~F}= \\
3)\end{array}$ & $\begin{array}{l}30 . \\
6 \\
(6 . \\
19)\end{array}$ & 20 & online & $\begin{array}{l}\text { SM } \\
\text { A }\end{array}$ & $\begin{array}{l}\text { Leg } \\
\text { mot } \\
\text { or } \\
\text { area } \\
\text { and } \\
\text { sha } \\
\mathrm{m}\end{array}$ & - & $\begin{array}{l}\text { Time } \\
\text { reprodu } \\
\text { ction } \\
\text { (stimula } \\
\text { tion } \\
\text { during } \\
\text { encodin } \\
\text { g or } \\
\text { reprodu } \\
\text { ction) }\end{array}$ & $\begin{array}{l}\text { Short } \\
=500 \\
\mathrm{~ms} \\
\text { (avera } \\
\text { ge); } \\
\text { Long } \\
= \\
2000 \mathrm{~m} \\
\mathrm{~s} \\
\text { (avera } \\
\text { ge) }\end{array}$ & $\begin{array}{l}\text { visua } \\
1\end{array}$ & $\begin{array}{l}\text { Reproduc } \\
\text { ed time }\end{array}$ & $\begin{array}{l}\text { No } \\
\text { effect }\end{array}$ \\
\hline $\begin{array}{l}\text { Kock } \\
\text { et al. } \\
(\mathbf{2 0 0 3})\end{array}$ & 1 & $\begin{array}{l}8(F= \\
4)\end{array}$ & $\begin{array}{l}\text { ran } \\
\text { ge } \\
19- \\
33\end{array}$ & 1 & offline & $\begin{array}{l}\text { DL } \\
\text { PFC }\end{array}$ & $\begin{array}{l}\text { base } \\
\text { line }\end{array}$ & $\begin{array}{l}\text { rig } \\
\text { ht } \\
\text { left }\end{array}$ & $\begin{array}{l}\text { Time } \\
\text { reprodu } \\
\text { ction }\end{array}$ & $\begin{array}{l}5 \text { or } \\
15 \mathrm{sec}\end{array}$ & $\begin{array}{l}\text { visua } \\
1\end{array}$ & $\begin{array}{l}\text { Reproduc } \\
\text { ed time } \\
\text { and SD }\end{array}$ & $\begin{array}{l}\text { Under- } \\
\text { estimati } \\
\text { on after } \\
\text { right }\end{array}$ \\
\hline
\end{tabular}




\begin{tabular}{|c|c|c|c|c|c|c|c|c|c|c|c|c|c|}
\hline & & & & & & & & & & & & & $\begin{array}{l}\text { side } \\
\text { stimulat } \\
\text { ion }\end{array}$ \\
\hline $\begin{array}{l}\text { Kock } \\
\text { et al. } \\
(2007)\end{array}$ & 1 & $9(-)^{* *}$ & $\begin{array}{l}\text { ran } \\
\text { ge } \\
22- \\
35\end{array}$ & 1 & offline & $\begin{array}{l}\text { DL } \\
\text { PFC }\end{array}$ & $\begin{array}{l}\text { base } \\
\text { line }\end{array}$ & $\begin{array}{l}\text { rig } \\
\text { ht }\end{array}$ & $\begin{array}{l}\text { Time } \\
\text { reprodu } \\
\text { ction }\end{array}$ & $\begin{array}{l}\text { Short } \\
=500 \\
\text { ms } \\
\text { (avera } \\
\text { ge); } \\
\text { Long } \\
=2000 \\
\text { ms } \\
\text { (avera } \\
\text { ge) }\end{array}$ & $\begin{array}{l}\text { visua } \\
1\end{array}$ & $\begin{array}{l}\text { Reproduc } \\
\text { ed time - } \\
\text { CV }\end{array}$ & $\begin{array}{l}\text { Over- } \\
\text { estimati } \\
\text { on long } \\
\text { range } \\
\text { interval } \\
\mathrm{s} \text {; no } \\
\text { effect } \\
\text { on CV }\end{array}$ \\
\hline
\end{tabular}

Note: $*$ = study that used subjects' MRI to localize the stimulation site; $* *=$ MRI was conducted for one participant after marking cerebellar and frontal scalp sites with capsules containing soy oil; SMA = Supplementary Motor Area; DLPFC $=$ Dorsolateral Prefrontal cortex $; \mathrm{SD}=$ Standard Deviation: $\mathrm{CV}=$ Coefficient of Variation 
Table 5. Studies that stimulated areas on Parietal cortex; Authors in alphabetic order

\begin{tabular}{|c|c|c|c|c|c|c|c|c|c|c|c|c|c|}
\hline $\begin{array}{l}\text { Autho } \\
\mathbf{r}\end{array}$ & $\begin{array}{l}\mathbf{E} \\
\mathbf{x} \\
\mathbf{p}\end{array}$ & $\begin{array}{l}\text { Partici } \\
\text { pants }\end{array}$ & $\begin{array}{l}\text { Ag } \\
\text { e } \\
\text { Me } \\
\text { an } \\
\text { (S } \\
\text { D) }\end{array}$ & $\begin{array}{l}T \\
M \\
S \\
\text { fre } \\
\text { q. } \\
\text { (H } \\
\text { z) }\end{array}$ & $\begin{array}{l}\text { Proce } \\
\text { dure }\end{array}$ & $\begin{array}{l}\text { ARE } \\
\text { A }\end{array}$ & Control & $\begin{array}{l}\text { Sid } \\
\text { e }\end{array}$ & $\begin{array}{l}\text { Tempo } \\
\text { ral } \\
\text { tasks }\end{array}$ & $\begin{array}{l}\text { Temp } \\
\text { oral } \\
\text { interv } \\
\text { als }\end{array}$ & $\begin{array}{l}\text { Mod } \\
\text { ality }\end{array}$ & $\begin{array}{l}\text { Depen } \\
\text { dent } \\
\text { variab } \\
\text { les }\end{array}$ & $\begin{array}{l}\text { Concl } \\
\text { usions }\end{array}$ \\
\hline $\begin{array}{l}\text { Alexa } \\
\text { nder } \\
\text { et al. } \\
(\mathbf{2 0 0 5})\end{array}$ & 1 & $\begin{array}{l}6(\mathrm{~F}= \\
2)^{*}\end{array}$ & $\begin{array}{l}30 . \\
5(- \\
)\end{array}$ & 1 & $\begin{array}{l}\text { offlin } \\
\text { e }\end{array}$ & $\begin{array}{l}\text { IPC } \\
\text { (angu } \\
\text { lar } \\
\text { gyrus } \\
\text { ) }\end{array}$ & $\begin{array}{l}\text { baseline } \\
\text { and } \\
\text { vertex }\end{array}$ & $\begin{array}{l}\text { rig } \\
\text { ht } \\
\text { left }\end{array}$ & $\begin{array}{l}\text { Time } \\
\text { discrimi } \\
\text { nation }\end{array}$ & 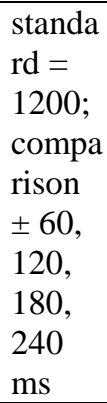 & $\begin{array}{l}\text { audit } \\
\text { ory }\end{array}$ & RT & $\begin{array}{l}\text { Higher } \\
\text { reactio } \\
\mathrm{n} \text { time } \\
\text { after } \\
\text { right } \\
\text { stimula } \\
\text { tion }\end{array}$ \\
\hline $\begin{array}{l}\text { Bolog } \\
\text { nini et } \\
\text { al. } \\
(2010)\end{array}$ & 1 & $\begin{array}{l}13(F= \\
6)\end{array}$ & $\begin{array}{l}\text { Me } \\
\text { an } \\
35\end{array}$ & 1 & $\begin{array}{l}\text { offlin } \\
\text { e }\end{array}$ & SI & - & left & $\begin{array}{l}\text { Time } \\
\text { discrimi } \\
\text { nation }\end{array}$ & $\begin{array}{l}\text { Standa } \\
\text { rd } 25 \\
\mathrm{~ms}\end{array}$ & $\begin{array}{l}\text { Tacti } \\
\text { le }\end{array}$ & $\begin{array}{l}\text { Percen } \\
\text { tage of } \\
\text { errors, } \\
\text { sensiti } \\
\text { vity } \\
\text { (d') } \\
\text { and } \\
\text { respon } \\
\text { se } \\
\text { criteri } \\
\text { on }\end{array}$ & $\begin{array}{l}\text { Increas } \\
\text { ed } \\
\text { numbe } \\
r \text { of } \\
\text { errors } \\
\text { for ISI } \\
=60 \\
\text { ms } \\
\text { compar } \\
\text { ed to } \\
\text { other } \\
\text { conditi } \\
\text { ons }\end{array}$ \\
\hline $\begin{array}{l}\text { Bueti } \\
\text { et al. } \\
(2008) \\
\text { a }\end{array}$ & 1 & $10(-)^{*}$ & $\begin{array}{l}29 . \\
2(- \\
)\end{array}$ & 12 & online & $\begin{array}{l}\text { IPC } \\
\text { (angu } \\
\text { lar } \\
\text { gyrus } \\
\text { ) }\end{array}$ & $\begin{array}{l}\text { NoTMS } \\
\text { and } \\
\text { Vertex }\end{array}$ & $\begin{array}{l}\text { rig } \\
\text { ht } \\
\text { left }\end{array}$ & $\begin{array}{l}\text { Time } \\
\text { discrimi } \\
\text { nation } \\
\text { (stimula } \\
\text { tion } \\
\text { over } \\
\text { compari } \\
\text { son } \\
\text { interval) }\end{array}$ & $\begin{array}{l}\text { standa } \\
\text { rd = } \\
600 \\
\text { ms; } \\
\text { compa } \\
\text { rison } \\
=435 \\
-765 \\
\text { ms }\end{array}$ & $\begin{array}{l}\text { visua } \\
1 \\
\text { movi } \\
\text { ng }\end{array}$ & $\begin{array}{l}\text { BP } \\
\text { and } \\
\text { WR }\end{array}$ & $\begin{array}{l}\text { Higher } \\
\text { variabi } \\
\text { lity } \\
\text { (WR) } \\
\text { after } \\
\text { right } \\
\text { IPC } \\
\text { stimula } \\
\text { tion }\end{array}$ \\
\hline $\begin{array}{l}\text { Bueti } \\
\text { et al. } \\
(2008) \\
\text { a }\end{array}$ & 2 & $10(-)^{*}$ & $\begin{array}{l}28 . \\
2(- \\
)\end{array}$ & 12 & online & $\begin{array}{l}\text { IPC } \\
\text { (angu } \\
\text { lar } \\
\text { gyrus } \\
\text { ) }\end{array}$ & $\begin{array}{l}\text { NoTMS } \\
\text { and } \\
\text { Vertex }\end{array}$ & $\begin{array}{l}\text { rig } \\
\text { ht } \\
\text { left }\end{array}$ & $\begin{array}{l}\text { Time } \\
\text { discrimi } \\
\text { nation } \\
\text { (stimula } \\
\text { tion } \\
\text { over } \\
\text { compari } \\
\text { son } \\
\text { interval) }\end{array}$ & $\begin{array}{l}\text { standa } \\
\text { rd = } \\
600 \\
\text { ms; } \\
\text { compa } \\
\text { rison } \\
=435 \\
-765 \\
\mathrm{~ms} \\
\end{array}$ & $\begin{array}{l}\text { visua } \\
1 \\
\text { static }\end{array}$ & $\begin{array}{l}\mathrm{BP} \\
\text { and } \\
\mathrm{WR}\end{array}$ & $\begin{array}{l}\text { Higher } \\
\text { variabi } \\
\text { lity } \\
\text { (WR) } \\
\text { after } \\
\text { right } \\
\text { IPC } \\
\text { stimula } \\
\text { tion } \\
\end{array}$ \\
\hline $\begin{array}{l}\text { Bueti } \\
\text { et al. } \\
(2008) \\
\text { a }\end{array}$ & 4 & $9(-)^{*}$ & $\begin{array}{l}29 . \\
6(- \\
)\end{array}$ & 12 & online & $\begin{array}{l}\text { IPC } \\
\text { (angu } \\
\text { lar } \\
\text { gyrus } \\
\text { ) }\end{array}$ & $\begin{array}{l}\text { NoTMS } \\
\text { and } \\
\text { Vertex }\end{array}$ & $\begin{array}{l}\text { rig } \\
\text { ht } \\
\text { left }\end{array}$ & $\begin{array}{l}\text { Time } \\
\text { discrimi } \\
\text { nation } \\
\text { (stimula } \\
\text { tion } \\
\text { over } \\
\text { compari } \\
\text { son } \\
\text { interval) }\end{array}$ & $\begin{array}{l}\text { standa } \\
\text { rd = } \\
600 \\
\text { ms; } \\
\text { compa } \\
\text { rison } \\
=435 \\
-765 \\
\mathrm{~ms} \\
\end{array}$ & $\begin{array}{l}\text { audit } \\
\text { ory }\end{array}$ & $\begin{array}{l}\mathrm{BP} \\
\text { and } \\
\mathrm{WR}\end{array}$ & $\begin{array}{l}\text { Higher } \\
\text { variabi } \\
\text { lity } \\
\text { (WR) } \\
\text { after } \\
\text { right } \\
\text { IPC } \\
\text { stimula } \\
\text { tion }\end{array}$ \\
\hline
\end{tabular}




\begin{tabular}{|c|c|c|c|c|c|c|c|c|c|c|c|c|c|}
\hline $\begin{array}{l}\text { Bueti } \\
\text { et al. } \\
(2008) \\
\text { a }\end{array}$ & 5 & $5(-)^{*}$ & $\begin{array}{l}28 \\
(-)\end{array}$ & 12 & online & $\begin{array}{l}\text { IPC } \\
\text { (angu } \\
\text { lar } \\
\text { gyrus } \\
\text { ) }\end{array}$ & $\begin{array}{l}\text { NoTMS } \\
\text { and } \\
\text { Vertex }\end{array}$ & $\begin{array}{l}\text { rig } \\
\text { ht }\end{array}$ & $\begin{array}{l}\text { Time } \\
\text { discrimi } \\
\text { nation } \\
\text { (stimula } \\
\text { tion } \\
\text { over } \\
\text { compari } \\
\text { son } \\
\text { interval) }\end{array}$ & $\begin{array}{l}\text { standa } \\
\text { rd = } \\
600 \\
\mathrm{~ms} ; \\
\text { compa } \\
\text { rison } \\
=520 \\
-680 \\
\mathrm{~ms}\end{array}$ & $\begin{array}{l}\text { audit } \\
\text { ory }\end{array}$ & $\begin{array}{l}\text { BP } \\
\text { and } \\
\text { WR }\end{array}$ & $\begin{array}{l}\text { Higher } \\
\text { variabi } \\
\text { lity } \\
\text { (WR) } \\
\text { after } \\
\text { right } \\
\text { IPC } \\
\text { stimula } \\
\text { tion }\end{array}$ \\
\hline $\begin{array}{l}\text { Dorm } \\
\text { al et } \\
\text { al. } \\
(\mathbf{2 0 0 8})\end{array}$ & 1 & $\begin{array}{l}15(\mathrm{~F}= \\
3)^{*}\end{array}$ & $\begin{array}{l}22 \\
(2 . \\
7)\end{array}$ & 1 & $\begin{array}{l}\text { offlin } \\
\mathrm{e}\end{array}$ & IPS & vertex & $\begin{array}{l}\text { rig } \\
\text { ht } \\
\text { left }\end{array}$ & $\begin{array}{l}\text { Time } \\
\text { discrimi } \\
\text { nation }\end{array}$ & $\begin{array}{l}\text { Interv } \\
\text { als } \\
\text { betwe } \\
\text { en } 300 \\
-900 \\
\text { ms } \\
\end{array}$ & $\begin{array}{l}\text { visua } \\
1\end{array}$ & RT & $\begin{array}{l}\text { No } \\
\text { effect }\end{array}$ \\
\hline $\begin{array}{l}\text { Dusek } \\
\text { et al. } \\
\text { (2011) }\end{array}$ & 1 & $\begin{array}{l}19(\mathrm{~F}= \\
11)\end{array}$ & $\begin{array}{l}25 . \\
9 \\
(3)\end{array}$ & $\begin{array}{l}\text { Th } \\
\text { eta } \\
\text { bur } \\
\text { st }\end{array}$ & $\begin{array}{l}\text { offlin } \\
\mathrm{e}\end{array}$ & $\begin{array}{l}\text { Precu } \\
\text { neus }\end{array}$ & - & - & $\begin{array}{l}\text { Time } \\
\text { reprodu } \\
\text { ction }\end{array}$ & $\begin{array}{l}5,10 \\
\text { and } \\
16.82 \\
\mathrm{~s}\end{array}$ & $\begin{array}{l}\text { visua } \\
1\end{array}$ & $\begin{array}{l}\text { Repro } \\
\text { duced } \\
\text { time; } \\
\text { SD } \\
\text { (variab } \\
\text { ility) }\end{array}$ & $\begin{array}{l}\text { No } \\
\text { effect } \\
\text { on } \\
\text { accura } \\
\text { cy; } \\
\text { Increas } \\
\text { ed } \\
\text { variabi } \\
\text { lity at } \\
5 \mathrm{~s} \\
\text { interva } \\
1\end{array}$ \\
\hline $\begin{array}{l}\text { Giova } \\
\text { nnelli } \\
\text { et al. } \\
(\mathbf{2 0 1 4})\end{array}$ & 1 & $\begin{array}{l}10(F= \\
7)\end{array}$ & $\begin{array}{l}29 . \\
1(- \\
)\end{array}$ & 1 & $\begin{array}{l}\text { offlin } \\
\mathrm{e}\end{array}$ & PPC & $\mathrm{Oz}$ & $\begin{array}{l}\text { rig } \\
\text { ht }\end{array}$ & $\begin{array}{l}\text { Time } \\
\text { discrimi } \\
\text { nation }\end{array}$ & $\begin{array}{l}\text { Standa } \\
\text { rd = } \\
1000 \\
\mathrm{~ms} ; \\
\text { compa } \\
\text { rison } \\
=800, \\
1000, \\
1200 \\
\mathrm{~ms}\end{array}$ & $\begin{array}{l}\text { audit } \\
\text { ory }\end{array}$ & $\begin{array}{l}\text { Percen } \\
\text { tage of } \\
\text { correct } \\
\text { respon } \\
\text { ses } \\
\text { and } \\
\text { RT }\end{array}$ & $\begin{array}{l}\text { No } \\
\text { effect } \\
\text { on } \\
\text { accura } \\
\text { cy; } \\
\text { faster } \\
\text { RT } \\
\text { after } \\
\text { stimula } \\
\text { tion }\end{array}$ \\
\hline $\begin{array}{l}\text { Oliver } \\
\text { i et al. } \\
(2009)\end{array}$ & 1 & $\begin{array}{l}10(\mathrm{~F}= \\
5)\end{array}$ & $\begin{array}{l}\text { ran } \\
\text { ge } \\
20- \\
30\end{array}$ & 1 & $\begin{array}{l}\text { offlin } \\
\text { e }\end{array}$ & $\begin{array}{l}\text { IPC } \\
\text { (angu } \\
\text { lar } \\
\text { gyrus } \\
\text { ) }\end{array}$ & baseline & $\begin{array}{l}\text { rig } \\
\text { ht } \\
\text { left }\end{array}$ & $\begin{array}{l}\text { Time } \\
\text { reprodu } \\
\text { ction }\end{array}$ & $\begin{array}{l}\text { standa } \\
\text { rd } \\
\text { interv } \\
\text { als } \\
\text { betwe } \\
\text { en } \\
1600 \text { - } \\
2400 \\
\text { ms } \\
\end{array}$ & $\begin{array}{l}\text { visua } \\
1\end{array}$ & $\begin{array}{l}\text { Repro } \\
\text { duced } \\
\text { time } \\
\text { and } \\
\text { absolu } \\
\text { te } \\
\text { error }\end{array}$ & $\begin{array}{l}\text { No } \\
\text { effect }\end{array}$ \\
\hline $\begin{array}{l}\text { Oliver } \\
\text { i et al. } \\
(2009)\end{array}$ & 1 & $\begin{array}{l}10(\mathrm{~F}= \\
5)\end{array}$ & $\begin{array}{l}\text { ran } \\
\text { ge } \\
20- \\
30\end{array}$ & 1 & $\begin{array}{l}\text { offlin } \\
\mathrm{e}\end{array}$ & $\begin{array}{l}\text { IPC } \\
\text { (angu } \\
\text { lar } \\
\text { gyrus } \\
\text { ) }\end{array}$ & baseline & $\begin{array}{l}\text { rig } \\
\text { ht } \\
\text { left }\end{array}$ & $\begin{array}{l}\text { Time } \\
\text { reprodu } \\
\text { ction }^{1} \\
\text { (half } \\
\text { reprodu } \\
\text { ction) }\end{array}$ & $\begin{array}{l}\text { standa } \\
\text { rd } \\
\text { interv } \\
\text { als } \\
\text { betwe } \\
\text { en } \\
1600 \text { - } \\
2400 \\
\text { ms }\end{array}$ & $\begin{array}{l}\text { visua } \\
1\end{array}$ & $\begin{array}{l}\text { Repro } \\
\text { duced } \\
\text { time } \\
\text { and } \\
\text { absolu } \\
\text { te } \\
\text { error }\end{array}$ & $\begin{array}{l}\text { Under- } \\
\text { estimat } \\
\text { ion } \\
\text { right } \\
\text { compar } \\
\text { ed to } \\
\text { left } \\
\text { side. }\end{array}$ \\
\hline
\end{tabular}




\begin{tabular}{|c|c|c|c|c|c|c|c|c|c|c|c|c|c|}
\hline $\begin{array}{l}\text { Oliver } \\
\text { i et al. } \\
\text { (2009) }\end{array}$ & 3 & $\begin{array}{l}7(\mathrm{~F}= \\
3)\end{array}$ & $\begin{array}{l}\text { ran } \\
\text { ge } \\
20- \\
33\end{array}$ & 20 & online & $\begin{array}{l}\text { IPC } \\
\text { (angu } \\
\text { lar } \\
\text { gyrus } \\
\text { ) }\end{array}$ & sham & $\begin{array}{l}\text { rig } \\
\text { ht }\end{array}$ & $\begin{array}{l}\text { Time } \\
\text { reprodu } \\
\text { ction } \\
\text { (stimula } \\
\text { tion } \\
\text { onset } \\
\text { encodin } \\
\text { g or } \\
\text { reprodu } \\
\text { ction) }\end{array}$ & $\begin{array}{l}\text { standa } \\
\text { rd } \\
\text { interv } \\
\text { als } \\
\text { betwe } \\
\text { en } \\
1600- \\
2400 \\
\text { ms }\end{array}$ & $\begin{array}{l}\text { visua } \\
1\end{array}$ & $\begin{array}{l}\text { Repro } \\
\text { duced } \\
\text { time } \\
\text { and } \\
\text { absolu } \\
\text { te } \\
\text { error }\end{array}$ & $\begin{array}{l}\text { No } \\
\text { effect }\end{array}$ \\
\hline $\begin{array}{l}\text { Oliver } \\
\text { i et al. } \\
\text { (2009) }\end{array}$ & 3 & $\begin{array}{l}7(F= \\
3)\end{array}$ & $\begin{array}{l}\text { ran } \\
\text { ge } \\
20- \\
33\end{array}$ & 20 & online & $\begin{array}{l}\text { IPC } \\
\text { (angu } \\
\text { lar } \\
\text { gyrus } \\
\text { ) }\end{array}$ & sham & $\begin{array}{l}\text { rig } \\
\text { ht }\end{array}$ & $\begin{array}{l}\text { Time } \\
\text { reprodu } \\
\text { ction } \\
\text { (half } \\
\text { reprodu } \\
\text { ction) } \\
\text { (stimula } \\
\text { tion } \\
\text { onset } \\
\text { encodin } \\
\text { g or } \\
\text { reprodu } \\
\text { ction) } \\
\end{array}$ & $\begin{array}{l}\text { standa } \\
\text { rd } \\
\text { interv } \\
\text { als } \\
\text { betwe } \\
\text { en } \\
1600 \text { - } \\
2400 \\
\text { ms }\end{array}$ & $\begin{array}{l}\text { visua } \\
1\end{array}$ & $\begin{array}{l}\text { Repro } \\
\text { duced } \\
\text { time } \\
\text { and } \\
\text { absolu } \\
\text { te } \\
\text { error }\end{array}$ & $\begin{array}{l}\text { Over- } \\
\text { estimat } \\
\text { ion } \\
\text { compar } \\
\text { ed to } \\
\text { sham } \\
\text { during } \\
\text { reprod } \\
\text { uction } \\
\text { phase }\end{array}$ \\
\hline $\begin{array}{l}\text { Rieme } \\
\text { r et al. } \\
\text { (2016) }\end{array}$ & 1 & $\begin{array}{l}24(\mathrm{~F}= \\
15)^{*}\end{array}$ & $\begin{array}{l}26 . \\
3(- \\
)\end{array}$ & $\begin{array}{l}\text { Th } \\
\text { eta } \\
\text { bur } \\
\text { st }\end{array}$ & $\begin{array}{l}\text { offlin } \\
\mathrm{e}\end{array}$ & IPS & sham & $\begin{array}{l}\text { rig } \\
\text { ht }\end{array}$ & $\begin{array}{l}\text { Time } \\
\text { reprodu } \\
\text { ction }\end{array}$ & $\begin{array}{l}\text { betwe } \\
\text { en } 1 \\
\text { and } 5 \\
\text { s }\end{array}$ & $\begin{array}{l}\text { audit } \\
\text { ory }\end{array}$ & $\begin{array}{l}\text { Relati } \\
\text { ve } \\
\text { error } \\
\text { and } \\
\text { CV }\end{array}$ & $\begin{array}{l}\text { No } \\
\text { effects }\end{array}$ \\
\hline $\begin{array}{l}\text { Rieme } \\
\text { r et al. } \\
(2016)\end{array}$ & 1 & $\begin{array}{l}24(\mathrm{~F}= \\
15)^{*}\end{array}$ & $\begin{array}{l}26 . \\
3(- \\
)\end{array}$ & $\begin{array}{l}\text { Th } \\
\text { eta } \\
\text { bur } \\
\text { st }\end{array}$ & $\begin{array}{l}\text { offlin } \\
\text { e }\end{array}$ & IPS & sham & $\begin{array}{l}\text { rig } \\
\text { ht }\end{array}$ & $\begin{array}{l}\text { Time } \\
\text { discrimi } \\
\text { nation }\end{array}$ & $\begin{array}{l}\text { standa } \\
\text { rd = 3 } \\
\text { s; } \\
\text { compa } \\
\text { rison } \\
\text { betwe } \\
\text { en } 2.5 \\
\text { and } \\
3.5 \mathrm{~s}\end{array}$ & $\begin{array}{l}\text { audit } \\
\text { ory }\end{array}$ & $\begin{array}{l}\text { PSE } \\
\text { and } \\
\text { DL }\end{array}$ & $\begin{array}{l}\text { Reduce } \\
\mathrm{d} \\
\text { uncerta } \\
\text { inty; } \\
\text { no } \\
\text { effect } \\
\text { on PSE }\end{array}$ \\
\hline $\begin{array}{l}\text { Rocha } \\
\text { et al. } \\
\text { (2019) }\end{array}$ & 1 & $\begin{array}{l}23(F= \\
11)\end{array}$ & $\begin{array}{l}24 . \\
2(- \\
)\end{array}$ & 1 & $\begin{array}{l}\text { offlin } \\
\text { e }\end{array}$ & SPC & sham & $\begin{array}{l}\text { me } \\
\text { dial }\end{array}$ & $\begin{array}{l}\text { Time } \\
\text { reprodu } \\
\text { ction }\end{array}$ & $\begin{array}{l}1,4,7 \\
\text { and } 9 \\
\text { s }\end{array}$ & $\begin{array}{l}\text { visua } \\
1\end{array}$ & $\begin{array}{l}\text { Absol } \\
\text { ute } \\
\text { and } \\
\text { relativ } \\
\text { e } \\
\text { errors }\end{array}$ & $\begin{array}{l}\text { Higher } \\
\text { accura } \\
\text { cy at } 4 \\
\text { and } 9 \mathrm{~s} \\
\text { after } \\
\text { stimula } \\
\text { tion. }\end{array}$ \\
\hline $\begin{array}{l}\text { Wiene } \\
\text { r et al. } \\
(2010) \\
\text { b }\end{array}$ & 1 & $\begin{array}{l}9(\mathrm{~F}= \\
4)\end{array}$ & $\begin{array}{l}\mathrm{Ra} \\
\text { nge } \\
23- \\
36\end{array}$ & 10 & online & SMG & $\begin{array}{l}\text { vertex/n } \\
\text { oTMS }\end{array}$ & $\begin{array}{l}\text { rig } \\
\text { ht } \\
\text { left }\end{array}$ & $\begin{array}{l}\text { Time } \\
\text { discrimi } \\
\text { nation } \\
\text { (stimula } \\
\text { tion } \\
\text { over } \\
\text { standard } \\
\text { interval) }\end{array}$ & $\begin{array}{l}\text { standa } \\
\text { rd = } \\
600 \\
\text { ms }\end{array}$ & $\begin{array}{l}\text { visua } \\
1\end{array}$ & $\begin{array}{l}\text { BP } \\
\text { and } \\
C V\end{array}$ & $\begin{array}{l}\text { Right: } \\
\text { decree } \\
\mathrm{d} \\
\text { proport } \\
\text { ion of } \\
\text { long } \\
\text { respon } \\
\text { ses } \\
\text { compar } \\
\text { ed to } \\
\text { vertex } \\
\text { and left } \\
\text { SMG }\end{array}$ \\
\hline
\end{tabular}




\begin{tabular}{|c|c|c|c|c|c|c|c|c|c|c|c|c|c|}
\hline $\begin{array}{l}\text { Wiene } \\
\text { r et al. } \\
(2010) \\
\text { b }\end{array}$ & 2 & $\begin{array}{l}17(F= \\
9)\end{array}$ & $\begin{array}{l}\mathrm{Ra} \\
\text { nge } \\
23- \\
35\end{array}$ & 10 & online & SMG & $\begin{array}{l}\text { vertex/n } \\
\text { oTMS }\end{array}$ & $\begin{array}{l}\text { rig } \\
\text { ht } \\
\text { left }\end{array}$ & $\begin{array}{l}\text { Time } \\
\text { discrimi } \\
\text { nation } \\
\text { (stimula } \\
\text { tion } \\
\text { over } \\
\text { compari } \\
\text { son } \\
\text { interval) }\end{array}$ & $\begin{array}{l}\text { standa } \\
\text { rd = } \\
600 \\
\mathrm{~ms}\end{array}$ & $\begin{array}{l}\text { visua } \\
1\end{array}$ & $\begin{array}{l}\text { BP } \\
\text { and } \\
\text { CV }\end{array}$ & $\begin{array}{l}\text { Right: } \\
\text { increas } \\
\text { ed } \\
\text { proport } \\
\text { ion of } \\
\text { long } \\
\text { respon } \\
\text { ses } \\
\text { compar } \\
\text { ed to } \\
\text { vertex } \\
\text { and left } \\
\text { SMG }\end{array}$ \\
\hline $\begin{array}{l}\text { Wiene } \\
r \text { et al. } \\
(2012)\end{array}$ & 1 & $\begin{array}{l}19(F= \\
9)\end{array}$ & $\begin{array}{l}\text { ran } \\
\text { ge } \\
21- \\
35\end{array}$ & 10 & $\begin{array}{l}\text { online } \\
2\end{array}$ & SMG & $\begin{array}{l}\text { baseline } \\
\text { / } \\
\text { midline } \\
\text { occipita } \\
1- \\
\text { parietal }\end{array}$ & $\begin{array}{l}\text { rig } \\
\text { ht }\end{array}$ & $\begin{array}{l}\text { Time } \\
\text { discrimi } \\
\text { nation } \\
\text { (stimula } \\
\text { tion } \\
\text { over } \\
\text { standard } \\
\text { interval) }\end{array}$ & $\begin{array}{l}\text { standa } \\
\text { rd = } \\
600 \\
\mathrm{~ms}\end{array}$ & $\begin{array}{l}\text { visua } \\
1\end{array}$ & $\begin{array}{l}\text { BP, } \\
\text { DL } \\
\text { and } \\
\text { CE }\end{array}$ & $\begin{array}{l}\text { Length } \\
\text { ened } \\
\text { time } \\
\text { for } \\
\text { short } \\
\text { and } \\
\text { long } \\
\text { interva } \\
\text { ls }\end{array}$ \\
\hline
\end{tabular}

Note: * = study that used subjects' MRI to localize the stimulation site; IPC = Inferior Parietal Cortex; SI = primary somatosensory cortex; IPS = Intra-parietal Sulcus; PPC = Posterior Parietal Cortex; SPC = Superior Parietal Cortex; SMG = Supra Marginal Gyrus; RT = Reaction time; $\mathrm{SD}=$ Standard Deviation; $\mathrm{BP}=$ Bisection point; WR Weber Ratio; CV Coeffient of Variation; DL = Different linen; $C E=$ Constant Error. 1 = Oliveri et al. (2009) called this task "rime bisection", we renamed it to avoid confusion with the classical time bisection task; $2=$ we defined this procedure as "online", specifically the stimulation occurred during the fixation cross in order to remove any confounding effects from TMS pulse on EEG recordings. 
Table 6. Studies that used tES; Authors in alphabetic order

\begin{tabular}{|c|c|c|c|c|c|c|c|c|c|c|c|c|c|}
\hline $\begin{array}{l}\text { Aut } \\
\text { hor }\end{array}$ & $\begin{array}{l}\text { Partici } \\
\text { pants }\end{array}$ & $\begin{array}{l}\text { Age } \\
\text { Mean } \\
\text { (SD) }\end{array}$ & \begin{tabular}{|l|} 
Type \\
of \\
stimul \\
ation
\end{tabular} & $\begin{array}{l}\text { Proce } \\
\text { dure }\end{array}$ & $\begin{array}{l}\text { Inten } \\
\text { sity }\end{array}$ & $\begin{array}{l}\text { ARE } \\
\text { A }\end{array}$ & $\begin{array}{l}\text { Spon } \\
\text { ges }\end{array}$ & Side & $\begin{array}{l}\text { Tempor } \\
\text { al tasks }\end{array}$ & \begin{tabular}{|l|} 
Temp \\
oral \\
interv \\
als \\
\end{tabular} & $\begin{array}{l}\text { Mod } \\
\text { ality }\end{array}$ & \begin{tabular}{|l|} 
Depen \\
dent \\
variab \\
les \\
\end{tabular} & $\begin{array}{l}\text { Conclus } \\
\text { ions }\end{array}$ \\
\hline $\begin{array}{l}\text { Java } \\
\text { di et } \\
\text { al. } \\
\text { (201 } \\
4)\end{array}$ & $\begin{array}{l}13(F= \\
7)\end{array}$ & $\begin{array}{l}22.18 \\
(2.18)\end{array}$ & $\begin{array}{l}\text { tDCS } \\
\text { anodal } \\
\text { cathod } \\
\text { al }\end{array}$ & $\begin{array}{l}\text { online } \\
- \\
\text { secon } \\
d \text { trial }\end{array}$ & 1.5 & $\begin{array}{l}\text { right/ } \\
\text { left } \\
\text { PPC }\end{array}$ & $\begin{array}{l}35 \times \\
35 \\
\mathrm{~mm} 2\end{array}$ & $\begin{array}{l}\text { Bilatera } \\
\text { lly } \\
\text { P3/P4 }\end{array}$ & $\begin{array}{l}\text { Time } \\
\text { discrimi } \\
\text { nation }\end{array}$ & $\begin{array}{l}800, \\
900, \\
1000, \\
1100, \\
\text { and } \\
1200 \\
\mathrm{~ms}\end{array}$ & $\begin{array}{l}\text { Visua } \\
1\end{array}$ & $\begin{array}{l}\text { Accur } \\
\text { acy } \\
\text { SD }\end{array}$ & $\begin{array}{l}\text { Reduced } \\
\text { accuracy } \\
\text { (anode } \\
\text { tDCS to } \\
\text { the left- } \\
\text { PPC and } \\
\text { cathode } \\
\text { tDCS to } \\
\text { the } \\
\text { right- } \\
\text { PPC) - } \\
\text { Increase } \\
\text { d } \\
\text { accuracy } \\
\text { (anode } \\
\text { tDCS to } \\
\text { the } \\
\text { right- } \\
\text { PPC and } \\
\text { cathode } \\
\text { tDCS to } \\
\text { the left- } \\
\text { PPC) }\end{array}$ \\
\hline $\begin{array}{l}\text { Mio } \\
\text { ni et } \\
\text { al. } \\
\text { (201 } \\
6)\end{array}$ & 24 & $\begin{array}{l}23.85 \\
(1.79)\end{array}$ & $\begin{array}{l}\text { tDCS } \\
\text { anodal } \\
\text { cathod } \\
\text { al }\end{array}$ & online & 1.5 & A1 & $\begin{array}{l}\text { Acti } \\
\text { ve }= \\
25 \\
\mathrm{~cm} 2 ; \\
\text { Retu } \\
\text { rn }= \\
35 \\
\mathrm{~cm} 2\end{array}$ & $\begin{array}{l}\text { Extrace } \\
\text { phalic }\end{array}$ & $\begin{array}{l}\text { Time } \\
\text { bisectio } \\
\text { n }\end{array}$ & $\begin{array}{l}\text { Stand } \\
\text { ard } \\
\text { short } \\
=300 \\
\mathrm{~ms} ; \\
\text { Stand } \\
\text { ard } \\
\text { long = } \\
900 \\
\mathrm{~ms}\end{array}$ & $\begin{array}{l}\text { Visua } \\
1 \\
\text { audit } \\
\text { ory }\end{array}$ & $\begin{array}{l}\text { BP } \\
\text { and } \\
\text { WR }\end{array}$ & $\begin{array}{l}\text { Higher } \\
\text { variabili } \\
\text { ty (WR) } \\
\text { under } \\
\text { anode } \\
\text { compare } \\
\text { d to } \\
\text { sham }\end{array}$ \\
\hline $\begin{array}{l}\text { Mio } \\
\text { ni et } \\
\text { al. } \\
\text { (201 } \\
6)\end{array}$ & 24 & $\begin{array}{l}25.16 \\
(3.34)\end{array}$ & $\begin{array}{l}\text { tDCS } \\
\text { anodal } \\
\text { cathod } \\
\text { al }\end{array}$ & online & 1.5 & V1 & $\begin{array}{l}\text { Acti } \\
\text { ve }= \\
25 \\
\mathrm{~cm} 2 ; \\
\text { Retu } \\
\mathrm{rn}= \\
35 \\
\mathrm{~cm} 2\end{array}$ & $\begin{array}{l}\text { Extrace } \\
\text { phalic }\end{array}$ & $\begin{array}{l}\text { Time } \\
\text { bisectio } \\
\mathrm{n}\end{array}$ & 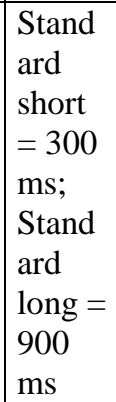 & $\begin{array}{l}\text { Visua } \\
1 \\
\text { audit } \\
\text { ory }\end{array}$ & $\begin{array}{l}\text { BP } \\
\text { and } \\
\text { WR }\end{array}$ & $\begin{array}{l}\text { Higher } \\
\text { variabili } \\
\text { ty }(\mathrm{WR}) \\
\text { under } \\
\text { cathode } \\
\text { only in } \\
\text { visual } \\
\text { modality }\end{array}$ \\
\hline $\begin{array}{l}\text { Mio } \\
\text { ni et } \\
\text { al. } \\
(201 \\
8)\end{array}$ & $\begin{array}{l}40(\mathrm{~F}= \\
20)\end{array}$ & $\begin{array}{l}23.04 \\
(1.87)\end{array}$ & $\begin{array}{l}\text { high } \\
\text { freque } \\
\text { ncy } \\
\text { tRNS }\end{array}$ & online & 1.5 & $\begin{array}{l}\text { right } \\
\text { Parie } \\
\text { tal } \\
(\mathrm{P} 4)\end{array}$ & $\begin{array}{l}\text { Acti } \\
\text { ve }= \\
16 \\
\mathrm{~cm} 2 ; \\
\text { Retu } \\
\mathrm{rn}= \\
60 \\
\mathrm{~cm} 2\end{array}$ & $\begin{array}{l}\text { Extrace } \\
\text { phalic }\end{array}$ & $\begin{array}{l}\text { Time } \\
\text { bisectio } \\
\mathrm{n}\end{array}$ & \begin{tabular}{|l} 
Stand \\
ard \\
short \\
$=300$ \\
ms; \\
Stand \\
ard \\
long = \\
900 \\
$\mathrm{~ms}$
\end{tabular} & $\begin{array}{l}\text { Visua } \\
1 \\
\text { audit } \\
\text { ory }\end{array}$ & $\begin{array}{l}\text { BP } \\
\text { and } \\
\text { WR }\end{array}$ & $\begin{array}{l}\text { Tempor } \\
\text { al over- } \\
\text { estimati } \\
\text { on (BP); } \\
\text { no effect } \\
\text { on } \\
\text { temporal } \\
\text { variabili } \\
\text { ty (WR) }\end{array}$ \\
\hline
\end{tabular}




\begin{tabular}{|c|c|c|c|c|c|c|c|c|c|c|c|c|c|}
\hline $\begin{array}{l}\text { Mio } \\
\text { ni et } \\
\text { al. } \\
(201 \\
8)\end{array}$ & $\begin{array}{l}40(\mathrm{~F}= \\
30)\end{array}$ & $\begin{array}{l}22.88 \\
(2.45)\end{array}$ & $\begin{array}{l}\text { high } \\
\text { freque } \\
\text { ncy } \\
\text { tRNS }\end{array}$ & online & 1.5 & \begin{tabular}{|l|} 
right \\
Front \\
al \\
(F4)
\end{tabular} & $\begin{array}{l}\text { Acti } \\
\text { ve = } \\
16 \\
\mathrm{~cm} 2 ; \\
\text { Retu } \\
\text { rn }= \\
60 \\
\mathrm{~cm} 2\end{array}$ & $\begin{array}{l}\text { Extrace } \\
\text { phalic }\end{array}$ & $\begin{array}{l}\text { Time } \\
\text { bisectio } \\
\mathrm{n}\end{array}$ & \begin{tabular}{|l|} 
Stand \\
ard \\
short \\
$=300$ \\
$\mathrm{~ms} ;$ \\
Stand \\
ard \\
long $=$ \\
900 \\
$\mathrm{~ms}$
\end{tabular} & $\begin{array}{l}\text { Visua } \\
1 \\
\text { audit } \\
\text { ory }\end{array}$ & $\begin{array}{l}\text { BP } \\
\text { and } \\
\text { WR }\end{array}$ & \begin{tabular}{|l} 
No \\
effect on \\
perceive \\
d \\
duration \\
(BP) \\
neither \\
temporal \\
variabili \\
ty (WR)
\end{tabular} \\
\hline $\begin{array}{l}\text { Mio } \\
\text { ni } \\
(201 \\
9)\end{array}$ & $\begin{array}{l}24(\mathrm{~F}= \\
8)\end{array}$ & $\begin{array}{l}23.88 \\
(3.66)\end{array}$ & $\begin{array}{l}\text { high } \\
\text { freque } \\
\text { ncy } \\
\text { tRNS }\end{array}$ & online & 1.5 & A1 & $\begin{array}{l}\text { Acti } \\
\text { ve }= \\
25 \\
\mathrm{~cm} 2 ; \\
\text { Retu } \\
\text { rn }= \\
35 \\
\mathrm{~cm} 2\end{array}$ & $\begin{array}{l}\text { Extrace } \\
\text { phalic }\end{array}$ & $\begin{array}{l}\text { Time } \\
\text { bisectio } \\
\mathrm{n}\end{array}$ & \begin{tabular}{|l|} 
Stand \\
ard \\
short \\
$=300$ \\
$\mathrm{~ms} ;$ \\
Stand \\
ard \\
long $=$ \\
900 \\
$\mathrm{~ms}$ \\
\end{tabular} & $\begin{array}{l}\text { Visua } \\
1 \\
\text { audit } \\
\text { ory }\end{array}$ & $\begin{array}{l}\text { BP } \\
\text { and } \\
\text { WR }\end{array}$ & $\begin{array}{l}\text { Tempor } \\
\text { al over- } \\
\text { estimati } \\
\text { on (BP); } \\
\text { no effect } \\
\text { on } \\
\text { temporal } \\
\text { variabili } \\
\text { ty (WR) }\end{array}$ \\
\hline $\begin{array}{l}\text { Mio } \\
\text { ni } \\
(201 \\
9)\end{array}$ & $\begin{array}{l}24(F= \\
8)\end{array}$ & $\begin{array}{l}23.22 \\
(2.65)\end{array}$ & $\begin{array}{l}\text { high } \\
\text { freque } \\
\text { ncy } \\
\text { tRNS }\end{array}$ & online & 1.5 & V1 & $\begin{array}{l}\text { Acti } \\
\text { ve = } \\
25 \\
\mathrm{~cm} 2 ; \\
\text { Retu } \\
\text { rn }= \\
35 \\
\mathrm{~cm} 2\end{array}$ & $\begin{array}{l}\text { Extrace } \\
\text { phalic }\end{array}$ & $\begin{array}{l}\text { Time } \\
\text { bisectio } \\
\mathrm{n}\end{array}$ & $\begin{array}{l}\text { Stand } \\
\text { ard } \\
\text { short } \\
=300 \\
\mathrm{~ms} \\
\text { Stand } \\
\text { ard } \\
\text { long }= \\
900 \\
\mathrm{~ms}\end{array}$ & $\begin{array}{l}\text { Visua } \\
1 \\
\text { audit } \\
\text { ory }\end{array}$ & $\begin{array}{l}\text { BP } \\
\text { and } \\
\text { WR }\end{array}$ & $\begin{array}{l}\text { Tempor } \\
\text { al over- } \\
\text { estimati } \\
\text { on (BP) } \\
\text { only in } \\
\text { visual } \\
\text { modality } \\
\text {; no } \\
\text { effect on } \\
\text { temporal } \\
\text { variabili } \\
\text { ty (WR) } \\
\end{array}$ \\
\hline $\begin{array}{l}\text { Oya } \\
\text { ma } \\
\text { et } \\
\text { al. } \\
\text { (201 } \\
7)\end{array}$ & $\begin{array}{l}16(F= \\
6)\end{array}$ & $\begin{array}{l}23.7 \\
(1.3)\end{array}$ & $\begin{array}{l}\text { tDCS } \\
\text { anodal } \\
\text { cathod } \\
\text { al }\end{array}$ & online & 2 & \begin{tabular}{|l|} 
right \\
Parie \\
tal \\
$(\mathrm{P} 4)$
\end{tabular} & $\begin{array}{l}\text { Acti } \\
\text { ve }= \\
5 \times 5 \\
\mathrm{~cm} 2 ; \\
\text { Retu } \\
\mathrm{rn}= \\
5 \times 7 \\
\mathrm{~cm} 2\end{array}$ & \begin{tabular}{|l} 
Supraor \\
bital \\
controla \\
teral
\end{tabular} & $\begin{array}{l}\text { Time } \\
\text { discrimi } \\
\text { nation }\end{array}$ & $\begin{array}{l}\text { Stand } \\
\text { ard } \\
600 \\
\mathrm{~ms}\end{array}$ & $\begin{array}{l}\text { Visua } \\
1\end{array}$ & $\begin{array}{l}\text { Thresh } \\
\text { old } \\
\text { and } \\
\text { SD }\end{array}$ & $\begin{array}{l}\text { Cathode } \\
\text { tDCS } \\
\text { enhance } \\
\text { s } \\
\text { temporal } \\
\text { discrimi } \\
\text { nation }\end{array}$ \\
\hline $\begin{array}{l}\text { Vica } \\
\text { rio } \\
\text { et } \\
\text { al. } \\
\text { (201 } \\
3 \text { ) }\end{array}$ & $\begin{array}{l}15(\mathrm{~F}= \\
9)\end{array}$ & \begin{tabular}{|l}
25.6 \\
$(3.41)$
\end{tabular} & $\begin{array}{l}\text { tDCS } \\
\text { anodal } \\
\text { cathod } \\
\text { al }\end{array}$ & online & 2 & $\begin{array}{l}\text { right } \\
\text { PPC }\end{array}$ & $\begin{array}{l}25 \\
\mathrm{~cm} 2\end{array}$ & $\begin{array}{l}\text { Bilatera } \\
\text { ly } \\
\text { P3/P4 }\end{array}$ & $\begin{array}{l}\text { Time } \\
\text { reproduc } \\
\text { tion }\end{array}$ & $\begin{array}{l}1500, \\
1600, \\
1700, \\
1800 \\
\text { and } \\
1900 \\
\mathrm{~ms}\end{array}$ & $\begin{array}{l}\text { Visua } \\
1\end{array}$ & $\begin{array}{l}\text { Accur } \\
\text { acy } \\
\text { CV }\end{array}$ & \begin{tabular}{|l} 
Over- \\
reproduc \\
tion \\
under \\
cathode \\
stimulati \\
on; no \\
effect of \\
anodal \\
\end{tabular} \\
\hline $\begin{array}{l}\text { Vica } \\
\text { rio } \\
\text { et } \\
\text { al. } \\
\text { (201 } \\
3 \text { ) }\end{array}$ & $\begin{array}{l}9(\mathrm{~F}= \\
5)\end{array}$ & \begin{tabular}{|l}
25.8 \\
$(3.88)$
\end{tabular} & $\begin{array}{l}\text { tDCS } \\
\text { anodal } \\
\text { cathod } \\
\text { al }\end{array}$ & online & 2 & $\begin{array}{l}\text { left } \\
\text { PPC }\end{array}$ & $\begin{array}{l}25 \\
\mathrm{~cm} 2\end{array}$ & \begin{tabular}{|l} 
Bilatera \\
lly \\
P3/P4
\end{tabular} & $\begin{array}{l}\text { Time } \\
\text { reproduc } \\
\text { tion }\end{array}$ & $\begin{array}{l}1500, \\
1600, \\
1700, \\
1800 \\
\text { and } \\
1900 \\
\mathrm{~ms}\end{array}$ & $\begin{array}{l}\text { Visua } \\
1\end{array}$ & $\begin{array}{l}\text { Accur } \\
\text { acy } \\
\text { CV }\end{array}$ & $\begin{array}{l}\text { Reduced } \\
\text { variabili } \\
\text { ty under } \\
\text { cathode } \\
\text { stimulati } \\
\text { on; no } \\
\text { effect of } \\
\text { anode }\end{array}$ \\
\hline
\end{tabular}


Note $: \mathrm{PPC}=$ Posterior Parietal Cortex; $\mathrm{A} 1=$ primary auditory area; $\mathrm{V} 1=$ primary visual area; $\mathrm{SD}=$ standard deviation; $\mathrm{BP}=$ Bisection point; $\mathrm{WR}=$ Weber ratio $\mathrm{CV}=$ Coefficient of variation. 